\title{
East European platform development in the Late Precambrian and Paleozoic: Structure and sedimentation
}

\author{
A. F. Grachev, and V. A. Nikolaev \\ Institute of Physics of the Earth, Russian Academy of Sciences, Moscow, Russia \\ V. G. Nikolaev \\ Geological Institute, Russian Academy of Sciences, Moscow, Russia \\ Received 25 August 2006; accepted 15 September 2006; published 18 October 2006.
}

[1] In spite of significant quantity of publications, devoted to different aspects of the East European (Russian) platform geology, the joint analysis of structure and sedimentation evolution has not been made. The paper deals with this subject and contains the most recent data. Litho-paleogeographic sketches of the East European platform are examined at different stages. Relations of major lithological complexes, mean rates of sedimentation, and areas covered by sea in Paleozoic and Mesozoic are revealed. The sketches representing structures of the East European platform sedimentary cover in the end of Riphean, in the end of Devonian, and in the end of Permian made it possible to distinguish major boundaries between reconstructions in structural plans. The role of inversion processes in separated local areas is underlined. The main structure of the Russian platform cover has been created during Riphean, Vendian to Early and Middle Paleozoic, and Late Paleozoic stages. The tendency in decreasing of the tectonic activity since Riphean through Mesozoic to Cenozoic takes shape. INDEX TERMS: 1033 Geochemistry: Intra-plate processes; 1165 Geochronology: Sedimentary geochronology; 1744 History of Geophysics: Tectonophysics; KEYWORDS: tectonics, structural geology, geodynamics, sedimentology, East European platform.

Citation: Grachev, A. F., V. A. Nikolaev, and V. G. Nikolaev (2006), East European platform development in the Late Precambrian and Paleozoic: Structure and sedimentation, Russ. J. Earth. Sci., 8, ES4001, doi:10.2205/2006ES000203.

\section{Introduction}

[2] East European platform (EEP) is considered to be one of the best studied among ancient platforms. Main features of its structure and geological development were described in a number of papers by Shatsky [1964]. The most important result of Shatsky's research was the recognition of aulacogens in the basement of East European platform. Initiation and subsequent degradation of aulacogens predetermined the main trend of Late Proterozoic and Paleozoic history of the platform. Shatsky was the first to note the important role of inversion in structural development of the platform sedimentary cover.

[3] In the light of modern data aulacogens are considered to be analogues to Cenozoic continental rifts [Grachev, 1987; Grachev and Fedorovsky, 1970]. Hence, during the sedimentation in the Late Proterozoic and Paleozoic the large

Copyright 2006 by the Russian Journal of Earth Sciences. ISSN: 1681-1208 (online) parts of the platform were no longer the areas of the stable conditions. It is evident that such changes must have been recorded in related formations including magmatic ones.

[4] In spite of numerous publications devoted to the different aspects of EEP geology the specialized analysis of its structure and sedimentation had not been made yet. This paper provides a new approach to the structure and sedimentary basins evolution during the Late Proterozoic and Paleozoic history of the platform, including the problem of inheritance.

\section{Main Features of the Sedimentation and Paleogeography}

[5] Initiation of aulacogen system in East European platform occurred in the end of Early Riphean. Sedimentation started with the deposition of coarse red-bed sediments. In middle Riphean these aulacogens were infilled by the finer marine terrigeneous sediments which are rep- 

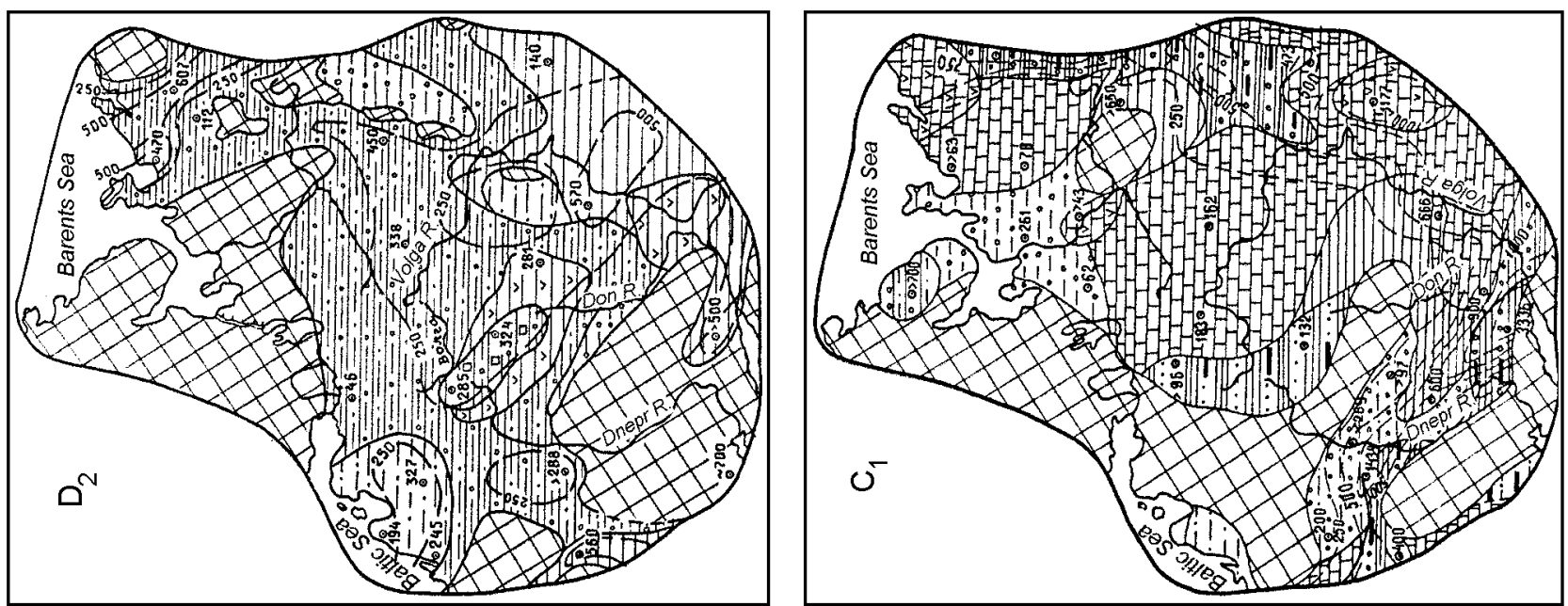

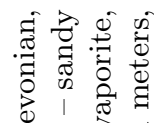

苟

足

空

กั

द. 屯 क

ن 00 \%

密

ठ 1 की

웡

荥离

ก

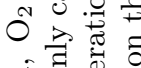

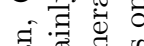
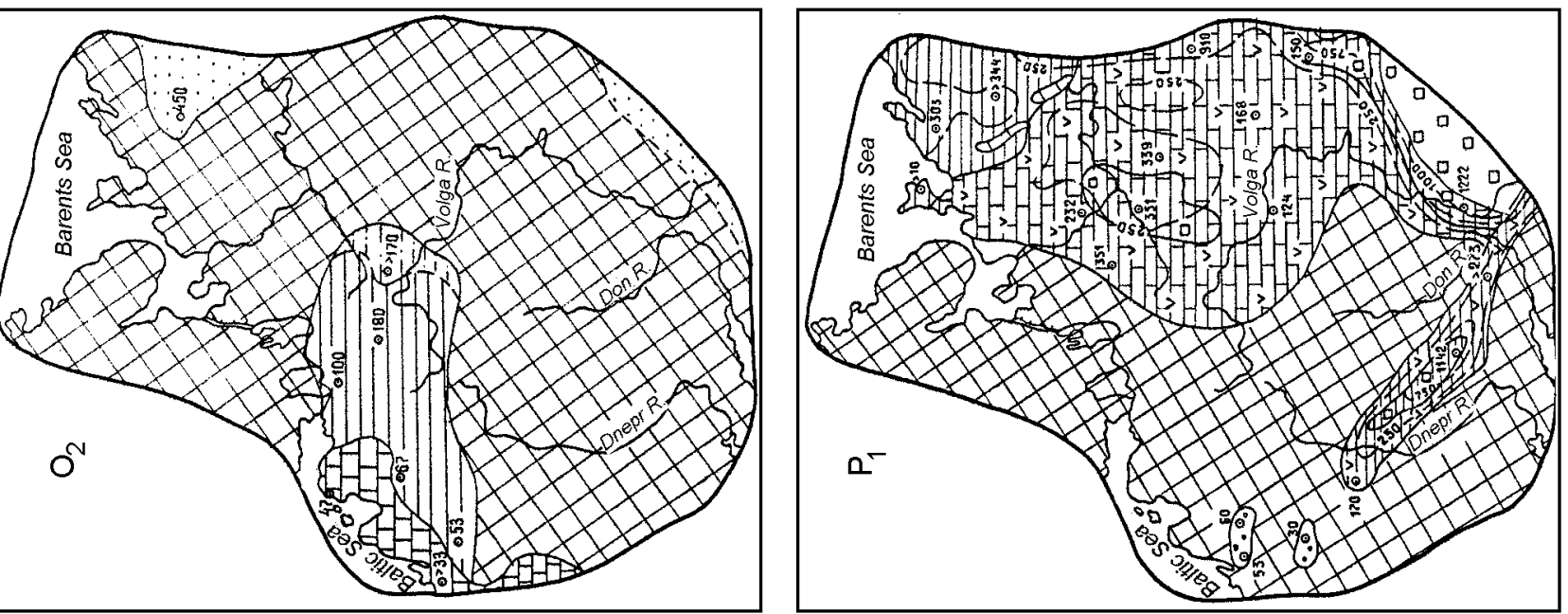

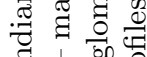

$>$ N

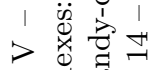

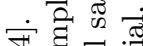

范

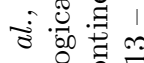

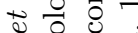

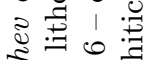

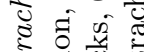

o

घ링

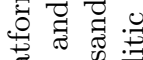

ㄴ. 눙

듀

只

胥

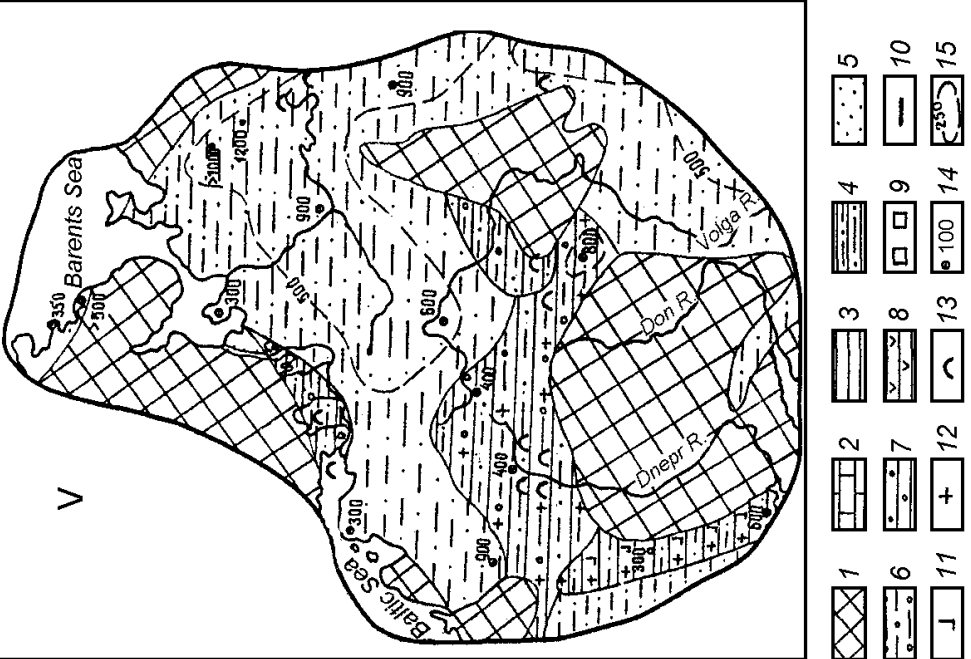

$\overrightarrow{0}-0$

田 $\dot{\square}$

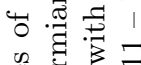

वै

它

ज

㽞

0 की $10 \bigcirc . \exists$

कo के की की

๙

응

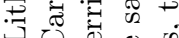

けU巳巳

- $\dot{0} \overrightarrow{0}$

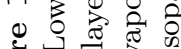

ज记

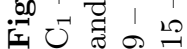


resented in a number of suits. These are Krestetskaya (Volyno-Krestetskiy area), Salminskaya (Ladozhskiy area), Salozerskaya (Onego-Kandalakshskiy area) and others. The thickness of these complexes is about several hundreds of meters in the Moscow (Srednerusskiy) aulacogen. The thickness increase up to $2-3 \mathrm{~km}$ in the Ryazano-Saratovskiy (Pachelmskiy) aulacogen. In the South-East of the platform the carbonate-terrigeneous complex was formed. This complex includes lower Riphean Tyrnitskaya, Inkashskaya, and Otrogovskaya suits of the Pachelmskiy aulacogen.

[6] Development of the aulacogen system continued in the Late Riphean. Main configuration of this system did not change significantly. Aulacogens were infilled with marine dominantly sandy complexes (ex.: Byelorussian series in the Srednerusskiy aulacogen; Somovskaya, Peresypkinskaya, and Pachelmskaya series in the Pachelmskiy aulacogen). Rates and scales of subsidience decreased in the South-East of the platform. Nevertheless, thickness of the Upper Riphean formations is about $2 \mathrm{~km}$, while thickness of aulacogens infillings do not exceed first hundreds of meters. Basic, intermediate, and acid effusives formed in the Pechora-Kolvinskiy aulacogen in the end of the Late Riphean.

[7] The formation of continuous sedimentary cover began in Middle Vendian about $650 \mathrm{Ma}$. The quantitative analysis of paleogeography and sedimentation in sedimentary basins revealed that their subsequent Paleozoic history of evolution could be clearly divided into several tectonic cycles. These cycles generally correspond to stages in evolution of active margins of the platform. These are Baikalian TimanoUralian and Bretono-Galitskaya, Caledonian Skandinavian, and Hercynian Uralian and Central-Dobruzhinsko-Caucasian [Seslavinsky, 1987].

[8] At the first stage since Vendian through Early and Middle Cambrian the main areas subsidience were situated in Pritiman'e, in Priural'e, and in Prikarpat'e (VislyandskoDnestrovskiy pericratonic basin). Subsidience also occurred around Srednerusskiy and Pachelmskiy aulacogens that led to formation of the large Baltic-Moscow basin, which occupied central part of the platform (Figure 1).

[9] The strong sheet-like glaciation affected larger part of the platform in the second half of the Early Vendian. Basaltic volcanism occurred in the south-western part of the platform (Volynskaya series). Marine deposits that were being formed during this stage in all inner basins are represented by terrigeneous mainly clayey rocks as thick as the first hundreds of meters. Thickness increased in marginal basins where sandy facies were widespread.

[10] In general, the role of uplifts was gradually increasing during the first stage. Before the Late Cambrian areas of marine basins and sedimentation rates decreased up to $14 \%$ in comparison with the total platform area.

[11] The development of the Baltic-Moscow basin continued during the next Late Cambrian to Early Devonian stage. This basin was parallel in strike with the Scandinavian fold belt system being separated from it by the Baltic shield. The Vislyandsko-Dnestrovskiy and Pricaspian basins also continued their development. Besides the east margin of the platform was submerged in the end of the stage and the sedimentary complexes of the Pechorskiy and Priuralian basins were being formed at this margin.
[12] Subsidence and marine sedimentary environments gradually occupied an ever-encreasing areas of the BalticMoscow basin during the first half of Ordovician. In the Middle Ordovician sea invaded in the Pechorskiy basin. These events caused the total increase (up to 35\%) of areas covered by marine basins to the beginning of the Middle Ordovician. Simultaneously, mean sedimentation rates increased indicating tectonic activisation. The comparison of these data with the mean sedimentation rates in the shelf zones of the Scandinavian foldbelt system indicates synchronous occurrence of the Middle Ordovician event. This corroborates the idea about the influence of Scandinavian Caledonides on tectonic development of sedimentary basins located in the north-western part of the platform.

[13] After the insignificant the Early Silurian regression in the Baltic-Moscow basin the total area covered by sea increased to more than $30 \%$ with subsequent decrease in the Early Devonian up to $10 \%$, that was the minimum for Paleozoic. All marine basins suffered global regression in the end of the Early Devonian stage. As an example, the Baltic-Moscow basin was transformed into the intracontinental drying up saline reservoir, where sandy-clayey alluvial and carbonate-terrigeneous lake sediments tens of meters in thickness were being formed.

[14] The composition of sediments deposited during this stage is more diverse than the composition of Vendian to Cambrian sediments. The presence of shallow carbonate muds, detrital limestones, and reef facies indicate the increasing role of carbonates. The reef facies are especially characteristic of Silurian deposits in the Priuralian basin. The highest mean sedimentation rate within the platform occurred in late Silurian during the final period of the stage.

[15] The significant reconstruction of platform structure occurred during the third stage in Devonian through Permian. Subsidence of the eastern and southern parts of the platform occurred in Middle to Late Devonian (see Figure 1, $\left.\mathrm{D}_{2}\right)$. This period of time was characterized by effusive and intrusive magmatism and by the formation of the Pripyatsko-Dneprovsko-Donetskiy aulacogen, the Donetsko-Caspian system of basins, and the ByelorussianVoronezhskaya zone of uplifts. The latter jutted out as a narrow ridge of the basement. The furrow of the KamskoKinel'skiy basins stretched parallel to the Urals in the East. Intensive subsidence of the entire eastern part of the platform that took place in the end of this stage led to formation of the large East Russian basin. The southern part of this basin had a junction with the Pricaspian basin (see Figure 1, $\left.\mathrm{C}_{1}, \mathrm{P}_{1}\right)$. Since the Kungurian age the latter became a depocenter of the saliferous complex that was followed in Permian to Triassic by the red-beds clastic complex.

[16] Thus, under the evident influence of intensive development of the Uralian and the Dobruzhinsko-Caucasian foldbelt systems the entire southern and eastern parts of the platform were affected by the largest Middle Devonian transgression which prograded westward from the Uralian system in the East. The very beginning of the Middle Devonian is characterized by sharp increase in sedimentation rates in Uralian basins and marine area became maximum to the end of the Givetian age. The correlation between the development of inner basins and mobile mar- 
gin accompanied by some delay, which is underlined by the data on the Late Devonian and Late Permian formations. The increase in rates of subsidence within the platform up to $23 \times 10^{-6} \mathrm{~m} \mathrm{years}^{-1}$ in Late Devonian and up to $30 \times 10^{-6} \mathrm{~m} \mathrm{years}^{-1}$ in late Permian was the reaction on intensive tectonic processes in the Uralian system in the Middle Devonian and Early Permian respectively.

[17] In general, the unstable regime existed within the platform during this stage. Regressions were followed by transgressions in some basins, and shallow-water sedimentary environments were transformed to relatively deep-water ones against the background of repeatedly occurring magmatism. Relatively dissected relief was being formed in land areas that resulted in the appearance of clastic continental rocks in appreciable amounts. These rocks exceeded $30 \%$ in abundance in the Late Permian. Carbonate sedimentation, including reef sedimentation, generally dominated and was extremely significant in the Late Devonian, Late Carboniferous, and Early Permian. Bituminous clays and oil shales (domanic) were widespread in the Priuralian basin in the Late Devonian. Gypsum and sporadically salt were deposited in several basins. Maximum salinization occurred in the second half of the Kungurian age. Since the Middle Devonian to the end of Carboniferous marine basins covered more than $2 / 3$ of the platform.

\section{Main Features of the Structure and Its Evolution}

[18] It is well known that modern structure of the platform comprises basement and sedimentary cover. Basement outcrops on the platform surface form two large shields: the Baltic and the Ukrainian ones. In the east the largest part of East European platform is occupied by the Russian plate which comprises deposits from the Riphean to Cenozoic. Traditionally basing on the basement surface depth large tectonic elements such as anteclises and syneclises could be recognized within the platform structure. The central part is occupied by the Moscow syneclise which stretches from Uralian to Valdai. The Baltic syneclise which opens into the West Europe is located westerly. The north-eastern and south-eastern flanks of the platform are occupied by Pechorskaya and Pricaspian syneclises, which nowadays are more often classified as basins. And at least, the L'vovskoLublinskiy downwarp (Ukrainian syneclise) stretches along the Carpathians to the South-West. The Voronezhskaya and the Volgo-Uralian anteclises predominate among positive structural elements in the Russian plate territory. The Ukrainian anteclise occupying the Ukrainian shield and adjacent areas also belongs to them.

[19] Several structural stages could be recognized on the basis of main angle disconformities and changes is structural plans [Garetsky, 1991; Zhuravlev, 1972]. Each of them contains smaller structural elements of different level. Age boundaries between large structural complexes could vary in different parts of the territory, but it is possible to trace general boundaries throughout the entire plate.
[20] The largest structural complexes are 1) Riphean, 2) Vendian to Lower Devonian, 3) Middle Devonian to Permian, and 4) Mesozoic to Cenozoic. We discuss only first three of them in the paper.

[21] An analysis of polychronous structural plans of the Russian plate sedimentary cover indicates that several structural reconstructions occurred during formation of the cover (Figures 2, 3, 4).

[22] The most sharp change could be identified at the boundary between the Early and Middle Vendian. Rift structures (aulacogens) are dominant among the Riphean and Early Vendian structures. Thickness of infilling deposits in such aulacogens is $10 \mathrm{~km}$ to $12 \mathrm{~km}$ [Shakhnovsky, 1988].

[23] These rift basins are bordered with large-scale faults of first kilometers in amplitude and hundreds kilometers in length. Riphean rifts could be divided into four groups differing in their spatial location (Figure 2). A system of adjacent rifts stretches from the North-East to the South-West almost across the entire Russian plate. This system is bordered by the Soligalichsko-Yaremskiy rift in the North-East, and by the Volynskiy basin in the South-East. The latter does not demonstrate definitely expressed fault boundaries. The Moscow aulacogen which is parallel to this system could be attributed to it.

[24] Three rifts occupying the north-western flank of the Russian plate have south-eastern strike (Ladozhskiy, OnegoKandalakshskiy, and Leshukonskiy) [Shakhnovsky, 1988]. Their northern ends could be traced into the territory of the Baltic shield and practically have not been expressed in the development of younger structures.

[25] Another paleorift system could be recognized in the eastern part of the East European platform [Sharipov, 1975]. The Kamsko-Kinel'skiy and similar in strike Vyatskiy paleorifts are parallel to the Uralian paleoocean. In spite of the fact that the Sernovodsko-Abdulinskiy aulacogen is directly adjacent to the Kamsko-Kinel'skaya system of grabens it is somewhat discordant with this system. Finally, the last system is composed by the Dneprovo-Donetskiy and the Ryazano-Saratovskiy (Pachelmskiy) aulacogens stretched subparallel in the north-western direction [Lukin et al., 1992; Proskuryakov et al., 1989; Shakhnovsky, 1988]. As far as these aulacogens open into the Pricaspian basin they are possibly connected with its Riphean structure. They predetermined delimitation of the three largest positive structures in the south-east of EEP: Ukrainian, Voronezhskiy, and Volgo-Uralian ones.

[26] The Pricaspian and the Pechorskiy basins occupy a specific place in Riphean structure of the platform. The data on Riphean history of the Pricaspian basin is very limited that only permits to suppose either the presence of paleorift system [Malushin, 1987] or the existence of large individual downwarps connected with the surrounding basins (particularly with the Uralian paleoocean) [Volozh, 1990]. The folding cycle in the Pechorskiy basin had been completed during Riphean and could not be correlated with initial stages in the formation of the Russian plate sedimentary cover [Dedeev et al., 1986; Getsen, 1991].

[27] Beginning from the Middle Vendian the total subsidence of EEP territory occurred. In the beginning it occupied the north-eastern flanks, stretching from the 


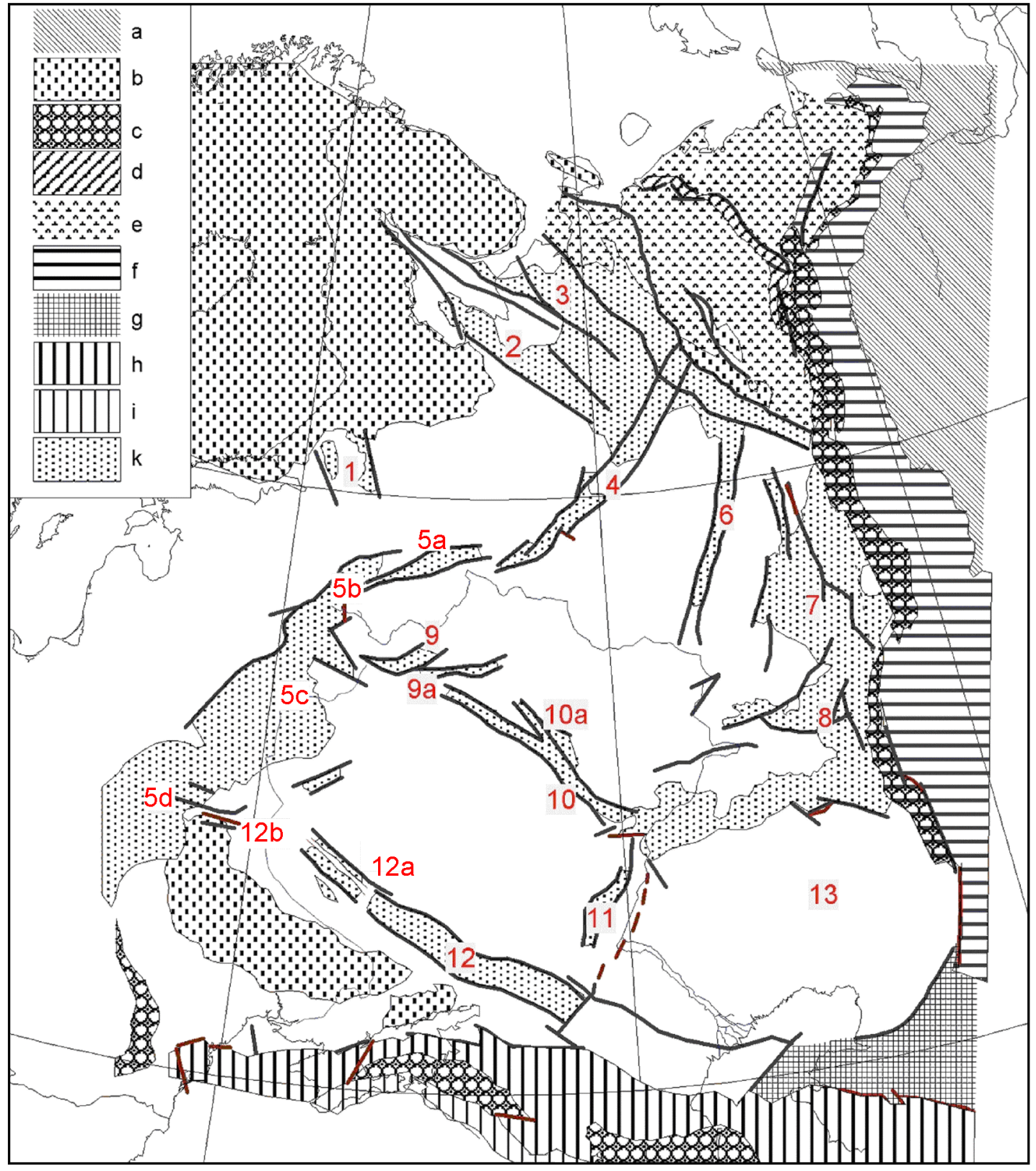

Figure 2. The sketch of the East-European platform sedimentary cover structures at the end of Riphean. $\mathrm{a}$ - West-Siberian plate, b - outcrops of the basement, $\mathrm{c}$ - foredeeps, $\mathrm{d}$ - basic Riphean rocks, e - folded Riphean of the Pechorskaya depression, $\mathrm{f}$ - Uralian fold belt, $\mathrm{g}$ - Ustyurtskiy block, $\mathrm{h}$ - Alpine folded belt, i - Skythsko-Turanskaya epiPaleozoic plate, $\mathrm{k}$ - boundary of Riphean deposits distribution. Ciphers - Riphean aulacogens: 1 - Ladozhskiy, 2 - Onego-Kandalakshskiy, 3 - Leshukonskiy, 4 - SoligalichskoYarenskiy, 5 - Volynsko-Krestovskiy: (5a - Krestovskiy, 5b - Valdayskiy, 5c - Orshanskiy graben, 5d Volynskiy graben), 6 - Vyatskiy, 7 - Kamsko-Bel'skiy, 8 - Sernovodsko-Abdulinskiy, 9 - Moscovskiy: (9a - Podmoskovnyy graben), 10 - Ryazano-Saratovskiy (Pachelmskiy), 11 - Dono-Medveditskiy, 12 Dneprovo-Donetskiy: (12a - Srebnenskaya depression, 12b - Ovruchskiy graben), 13 - PriCaspian basin (supposed rift system) 


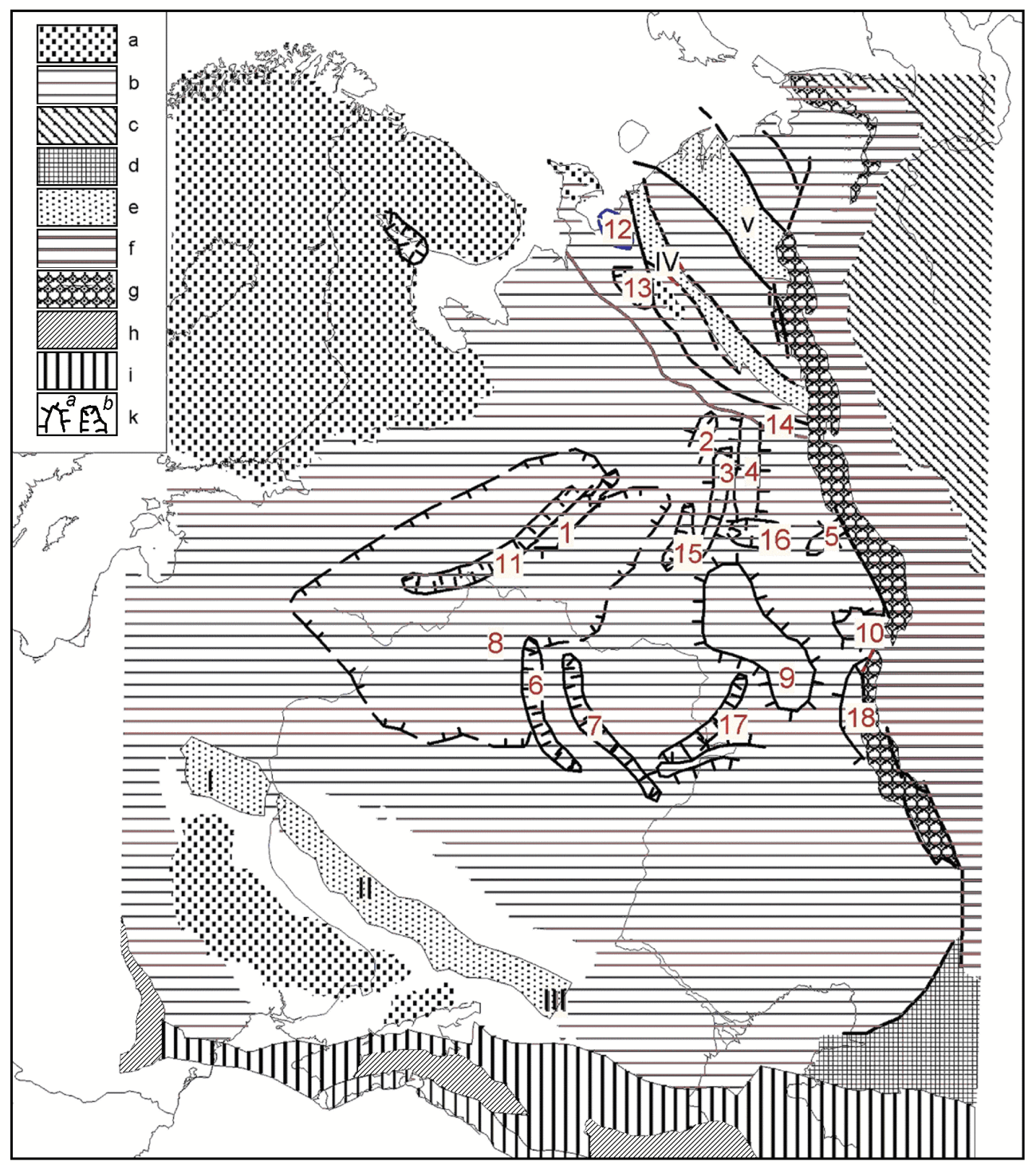

Figure 3. The sketch of the East-European platform sedimentary cover structures at the end of Devonian. a - outcrops of the basement, $\mathrm{b}$ - the area of the Vendian-Devonian deposits distribution, $\mathrm{c}-$ West-Siberian plate, d - Ustyurtskiy block, e - Devonian rift troughs: I - Pripyatskiy, II - Dneprovskiy, III - Donetskiy, IV - Timanskiy, V - Pechorsko-Kolvinskiy; f - Uralian folded belt, g - Predural'skiy foredeep, $\mathrm{h}$ - Alpine folded belt, i - Predal'piyskiy foredeep, $\mathrm{k}$ - anticlines $(a)$ and synclines $(b): 1-$ Sukhonskaya, 2 - Sysol'skaya, 3 - Vyatskaya, 4 - Komi-Permyatskaya, 5 - Permskaya, 6 - OkskoTsninskaya, 7 - Tokmovskaya, 9 - Tatarskaya, 10 - Bashkirskaya, 12 - Peshskaya, 13 - Safonovskaya, 14 - Vychegodskaya, 15 - Sysol'skaya, 16 - Verkhnekamskaya, 17 - Melekesskaya, 18 - Bel'skaya. 


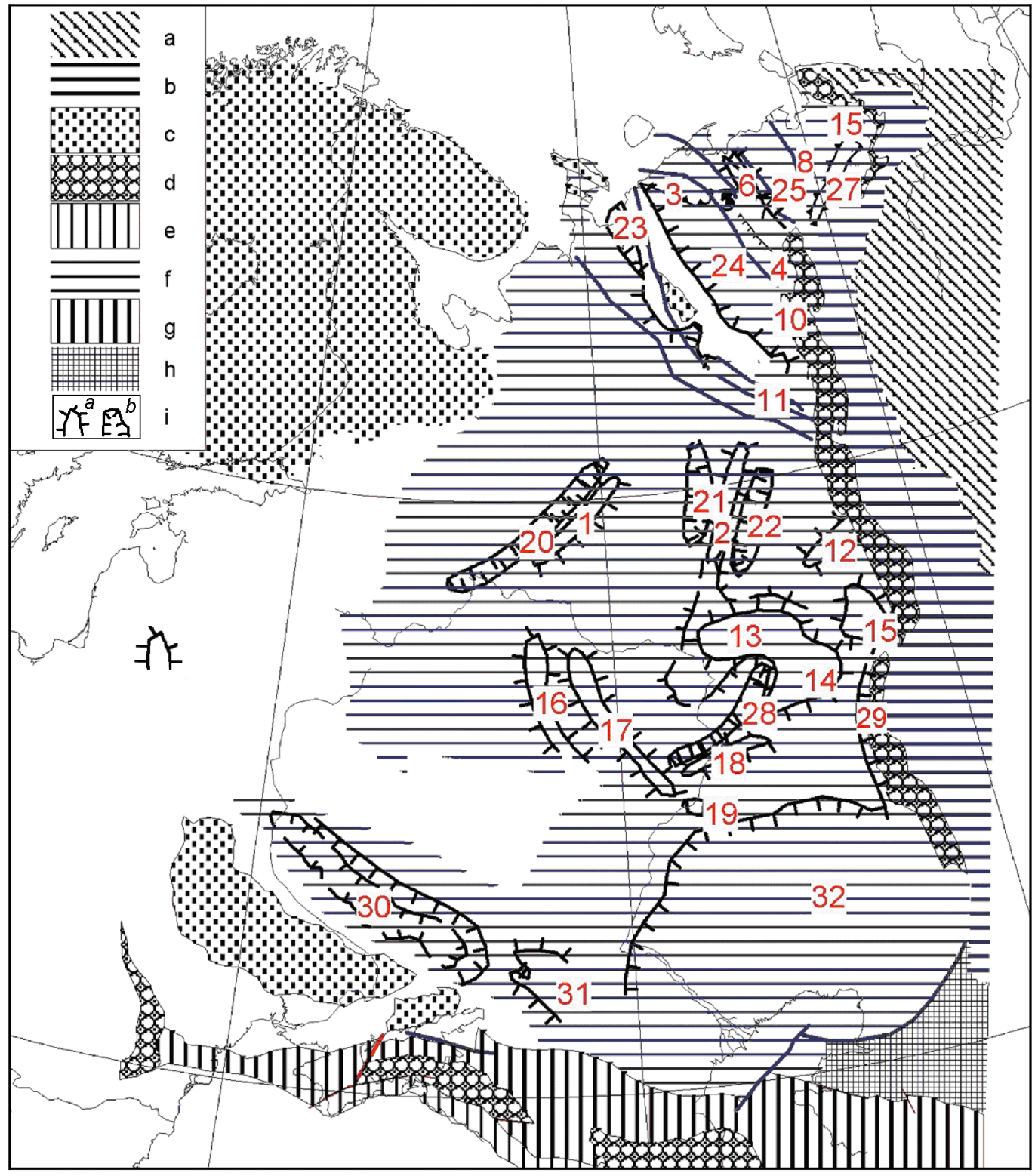

Figure 4. The sketch of the East-European platform sedimentary cover structures at the end of Permian. a - West-Siberian plate, b - Uralian fold belt, c - outcrops of the basement, d foredeeps, e - Alpine folded, $\mathrm{f}$ - area of the Carboniferous to Permian deposits distribution, $\mathrm{g}-$ Skythsko-Turanskaya EpiPaleozoic plate, h - Ustyurtskiy block, i - local structures: $a$ - anticlines, $b$ - synclines (1 - Sukhonskaya, 2 - Vyatskaya, 3 - Seduyakhinskaya, 4 - Pechoro-Kozhvinskaya, 5 Shapkinskaya, 6 - Layskaya, 7 - Kolvinskaya, 8 - Sorokina, 9 - Gamburtseva, 10 - Michayusskaya, 11 - Yuzhnotimanskaya, 12 - Permskaya, 13 - Kukmorskaya, 14 - Al'met'evskaya, 15 - Bashkirskaya, 16 - Oksko-Tsninskaya, 17 - Tokmovskaya, 18 - Zhigulevskaya, 19 - Balaklavskaya, 20 - LubimskoSoligalichskaya, 21 - Sysol'skaya, 22 - Verkhnekamskaya, 23 - Peshskaya, 24 - Pechorskaya, 25 Khoreyverskaya, 26 - Korotaikhinskaya, 27 - Kos'yu-Rogovskaya, 28 - Melekesskaya, 29 - Bel'skaya, 30 - Dneprovo-Donetskaya, 31 - Tsimlyanskaya, 32 - Prikaspiyskaya). 
Pechorskaya depression to the south-west up to the L'vovskoPridnestrovskaya zone of subsidence. Vendian deposits are absent in the Byelorussian syneclise as well as across the entire south-eastern margin of the platform which includes Ukranian and Volgo-Uralian anteclises. The most significant subsidence was restricted to the axial zone of the Riphean Soligalichsko-Yaremskiy aulacogen.

[28] The discordance in Vendian structural plan with the previous structures is evident. A very gentle Vendian monocline is located crosswise to the northern group of Riphean grabens. The Soligalichskaya anticline is restricted to central part of the Soligalichsko-Yaremskiy graben, while to the west and east from it syneclises are located along the strike of the ancient structure. We traced the closing of the Lubimsko-Soligalichskaya anticline in the northern part of the Valdaiskiy graben.

[29] The northern flank of the Byelorussian anteclise is located in the southern part of the graben. Riphean Moscowskiy and Ryazano-Saratovskiy aulacogens have no significant expression in Vendian structural plan. The Oksko-Tsninskaya anticline corersponds to the branch of the same name within the Ryazano-Saratovskiy aulacogen.

[30] To the east in Priural'e at the former location of Riphean Kamsko-Kinel'skaya system of depressions two anticlines (Permskaya and Bashkirskaya) are oriented crosswise to the ancient strike. A negative structure corresponding to the Vyatskiy graben is partly preserved northerly. It is surrounded from both sides by Sysol'skaya and KomiPermyatskaya anticlines. Vendian monocline corresponds to Sernovodsko-Abdulinskiy aulacogen.

[31] In the Early to the Middle Paleozoic the subsidence area has increased. This event was characterized by differentiation in rates of sedimentation. In Ordovician to Silurian maximum values occurred in the south-western flank of the platform where the new L'vovsko-Pridnestrovskaya depression (the zone of pericratonic subsidence) was formed and the Baltic syneclise was located to the north from it where the subsidence areas have not been compensated by sediments [Garetsky et al., 1990]. Beginning from the Devonian, these structures of the cover were inactive.

[32] The next stage of subsidence started in Permian and only within the Baltic syneclise. In the east significant areas were involved in subsidence during the Ordovician to Silurian. Within the Pechorskaya depression this process was accompanied by the formation of local platform structures.

[33] Since the middle Devonian central and eastern parts of the Russian plate became the main area of subsidence. Sedimentation was absent only at the White sea coast, within the Ukrainian shield and in the narrow band along southern slope of the Voronezhskaya anteclise. During Devonian substage the majority of structures inherited Vendian ones. First of all these are synclines and anticlines of the Moscow syneclise axial part and Priuralian structures (Permian and Bashkirian anticlines). At the same time either formation of new structural forms or inversion of movements along previous structures occurred during Devonian stage.

[34] New structures can be represented by the Tokmovskaya and Balakovskaya anticlines as well as by the sys- tem of uplifts near the Tatarskaya anticline (Figure 3). The Zhigulevskaya anticline corresponds to the southern termination of Riphean Sernovodsko-Abdulinskiy aulacogen. Adjacent Melekesskaya syncline was generally restricted to the northern boundary of the same aulacogen. The Umetovsko-Linevskiy downwarp arised to the west from the Pricaspian basin. The Devonian Vyatskaya anticline was formed directly along its axis. Sysol'skaya and Verkhnekamskaya synclines inherited the place of the former location of Vendian positive structures. The northernmost Peshskaya syncline existed northerly at the place of elongataed Vendian downwarp which included Vychegodskaya, Safonovskaya, and Peshskaya synclines.

[35] New stage of rifting occurred in middle Devonian. Dneprovo-Donetskiy aulacogen completely coincided with the area of Riphean aulacogen of the same name. The Pripyatskiy graben accompanied it in Devonian. The westernmost part of this graben crossed Riphean structure of the Volyno-Orshanskiy downwarp. New rifts were formed within the Pechorskiy basin [Dedeev, 1982]. There is no clear evidence (possibly due to the lack of data) on the direct connection with structures of ancient horizons of the cover.

[36] During Devonian the Pricaspian basin had outlines similar in shape to the recent one and developed as a noncompensated area of submergence with maximum subsidence in the Late Devonian [Volozh, 1990; Yanshin et al., 1979]. Uplifts of the basement (Astrakhanskiy arch, etc.) formed along its peripheral parts. Being a small oceanic basin the Pricaspian basin was most probably connected with Paleozoic oceans: Uralian and Paleo-Tethys.

[37] Non-compensated basins were widely presented during Vendian to the Middle Paleozoic but irregularly distributed in the platform territory [Garetsky et al., 1991]. Along south-western flank of EEP these basins developed within the Baltic-Pridnestrovskaya zone of pericratonic subsidence. The most significant stages of non-compensated downwarp in Baltic and Volynskiy basons occurred in Ordovician, Silurian, and Devonian. Boundaries of sedimentary basins changed during these stages. The Baltic non-compensated downwarp reached the maximum size in Ordovician with subsequent gradual decrease. On the contrary the Volynskiy downwarp increased through Ordovician to Silurian. During the most part of Devonian such downwarps were absent in the south-west of EEP.

[38] In the eastern part of the platform the maximum of non-compensated subsidence occurred in the Late Devonian near the Uralian mobile belt. Within the Pechorskiy basin the main zone of submergence was situated close to Urals and had a stable eastern boundary. Its area decreased in the west direction during the Frasnian and late Famennian stages (Figure 4).

[39] To the south the huge non-compensated isometric Pricaspian basin was located southerly. It existed in the Late Devonian and continued its development in the Carboniferous and Early Permian (Figure 4). Its boundaries did not correspond to boundaries of the Pricaspian syneclise and, as a rule, were shifted to center of negative structure. Upper Devonian Umetovsko-Linevskiy downwarp is located to the west from the Pricaspian basin being connected with it by the narrow strait. It coincides in space 
with the area of Riphean Dono-Medveditskiy graben.

[40] The Pripyatsko-Dneprovo-Donetskiy graben is an example of the most complete coincidence of the formation of non-compensated downwarping with rifting process. Here the non-compensated sedimentation was most active in late Frasnian to Famennian and then continued in the Carboniferous and Early Permian. During the Late Devonian the main phase was subdivided in several subphases of non-compensated and compensated sedimentation. The downwarping began in the south-eastern flank of the structure in the Donbass area and up to the Late Frasnian gradually invaded areas to the North-East towards the Pripyatskiy graben. The depression with maximum depth up to $600-700 \mathrm{~m}$ in the central part was formed in the Famennian on the territory of the Pricaspian graben. It is possible that similar environments also existed in other noncompensated downwarps of the Dneprovo-Donetskiy rift.

[41] Thus, the formation of sedimentary cover of EEP since Riphean through the end of Paleozoic was accompanied by several structural reconstructions of different significance. The principle change in structural pattern occurred at Early to Late Vendian boundary. This period was characterized by the replacement of contrasting in subsiding amplitudes rift structures (aulacogens) with more gentle platform structures. During Riphean the platform was in a conditions of a stretching that were changed later by epeirogenesis with different structural and geomorphological expression. These movements were differentiated in time and caused changes of the structural pattern. But the main feature of these reconstructions consists in the development of inversion processes. At the same time outlines and localities of structures did not change as a rule. Only in individual cases it is possible to observe small lateral shift of anticlinal arch or lower part of syncline. During Vendian through Paleozoic the areas of inversion were connected with some Riphean rifts. These are restricted to the southern part of the Soligalichsko-Yaremskiy and Vyatskiy rifts as well as to the Oksko-Tsninskaya branch of the Ryazano-Saratovskiy rift. Other Riphean structures and their parts either have no expression in the cover structures or negative movements continued on their territories (Kamsko-Bel'skiy aulacogen, etc.).

[42] Thus, the formation of sedimentary cover of EEP since Riphean through the end of Paleozoic was accompanied by several structural reconstructions of different significance. The principle change in structural pattern occurred at Early to Late Vendian boundary. This period was characterized by the replacement of contrasting in subsiding amplitudes rift structures (aulacogens) with more gentle platform structures. During Riphean the platform was in a conditions of a stretching that were changed later by epeirogenesis with different structural and geomorphological expression. These movements were differentiated in time and caused changes of the structural pattern. But the main feature of these reconstructions consists in the development of inversion processes. At the same time outlines and localities of structures did not change as a rule. Only in individual cases it is possible to observe small lateral shift of anticlinal arch or lower part of syncline. During Vendian through Paleozoic the areas of inversion were connected with some Riphean rifts. These are concentrated in the southern part of the Soligalichsko-Yaremskiy and Vyatskiy rifts as well as to the Oksko-Tsninskaya branch of the Ryazano-Saratovskiy rift. Other Riphean structures have no expression in the cover structures or negative movements continued on their territories (Kamsko-Bel'skiy aulacogen, etc.).

[43] Zones of inversion tend to locate in the proximity to Riphean rifts shoulders. This is most expressive in the area of the Vyatskiy aulacogen, where Vendian anticlines were replaced by Devonian synclines on the same very area. In the Carboniferous inversion took place within the Pechorskiy basin. The southern part of the Laiskaya anticline crosses the central part of the graben. At the same time Carboniferous to Permian monocline, complicated by structural noses and inlets, is located above the Devonian Timanskiy rift.

[44] There is significant dispersion of inversion processes through time. Sometimes changes in movements occurred immediately after the end of aulacogen formation (ex.: Vendian anticlines on Riphean Soligalichsko-Yaremskiy and Oksko-Tzninskiy aulacogens). In other cases inversion took place after hundreds millions years and in adjacent territories. This is characteristic of southern part of RyazanoSaratovskiy aulacogen where the southern part of the OkskoTsninskaya anticline was formed in Devonian after the existence of the pre-Devonian uplift that occupied territory from the Voronezhskaya anteclise to the southern part of the Volgo-Uralian anteclise.

[45] The main structure of the Russian plate cover was formed during Riphean, Vendian to the Early and middle Paleozoic and the Late Paleozoic stages. Later stages were mainly characterized by the formation of large syneclises.

\section{On the Inheritance Patterns in the Structural Development of the East European Platform}

[46] Notwithstanding extensive studies of various aspects of the East European platform (EEP) geology, the problem of inheritance has largely been unsolved. The method of principal components was applied to the comparative analysis of the maps of sedimentary thickness cover and the structural maps constructed by V. V. Bronguleev for the EEP [Bronguleev, 1978]. For this purpose, the maps were digitized on a $20 \times 30$ (Figures 5 and 6 ). Tables $1-3$ present results of correlation and factor analysis showing that the sedimentation inheritance is recognizable only at certain sedimentary stages in some regions. This is well illustrated in Figure 7, showing the maps of time intervals in which this feature is observed.

[47] The application of the factor analysis to the maps of thicknesses of EEP sediments revealed eight significant factors (Tables 1-3) mapped in Figure 7. As a result, using the factor analysis, 8 sedimentation areas were delineated for 24 epochs of sedimentation. The most stable areas with the longest development of sedimentation are observed in $\mathrm{T}_{1}-\mathrm{J}_{2}$ and (to a lesser extent) in $\mathrm{K}_{1}-\mathrm{K}_{2}$. The shortest sedimentation interval existed in the Late Jurassic $\left(\mathrm{J}_{3}\right)$. The sedimentation basins changed their structure 10 times over 

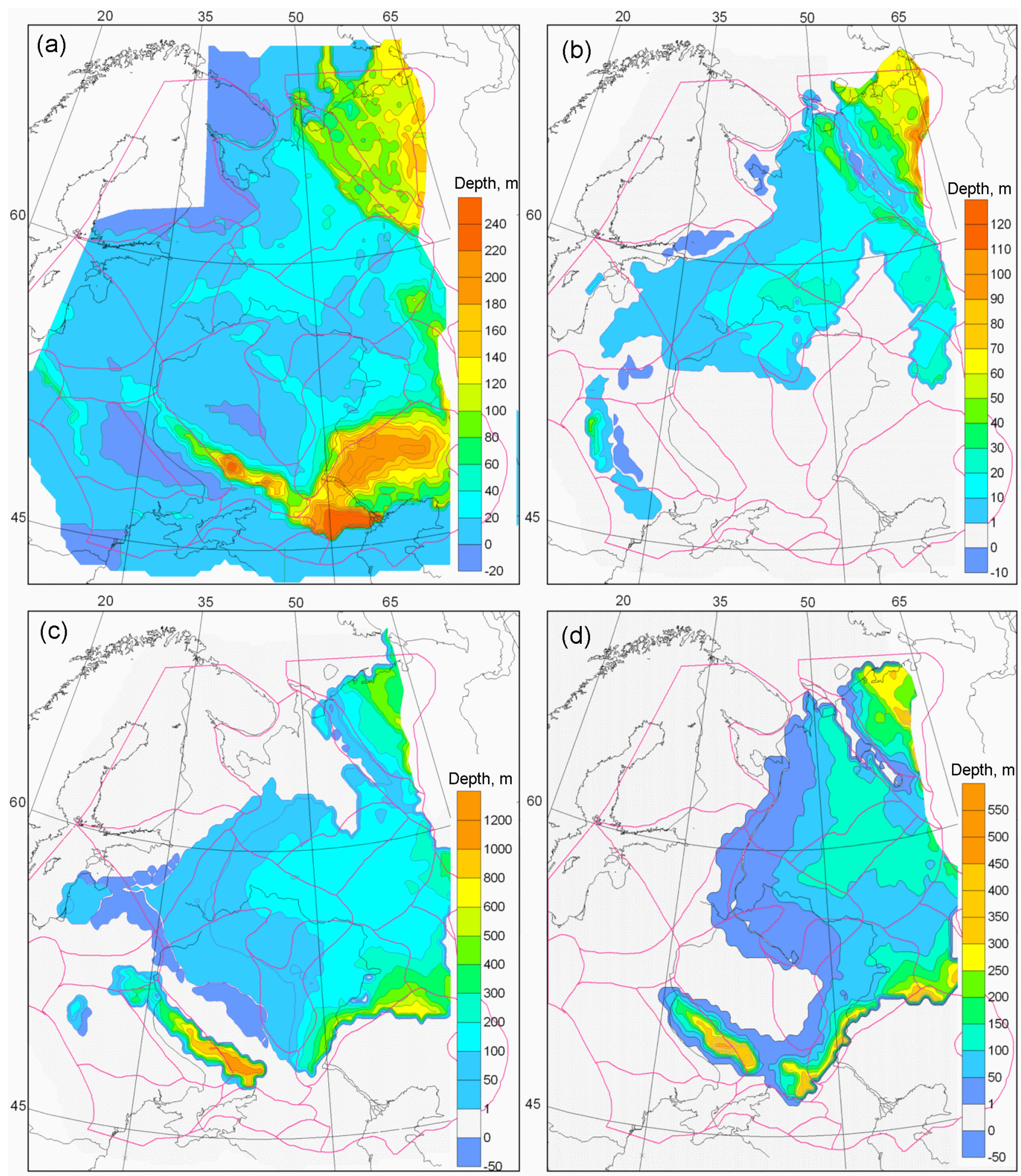

Figure 5. Structural maps on the top of basement (a), Vendian (b), Upper Devonian, Sartansky horizon, Frasnian stage (c), Middle Carboniferous, Vereiskian horizon, Moscovian stage (d), and Lower Permian, Artinskian stage (e). 


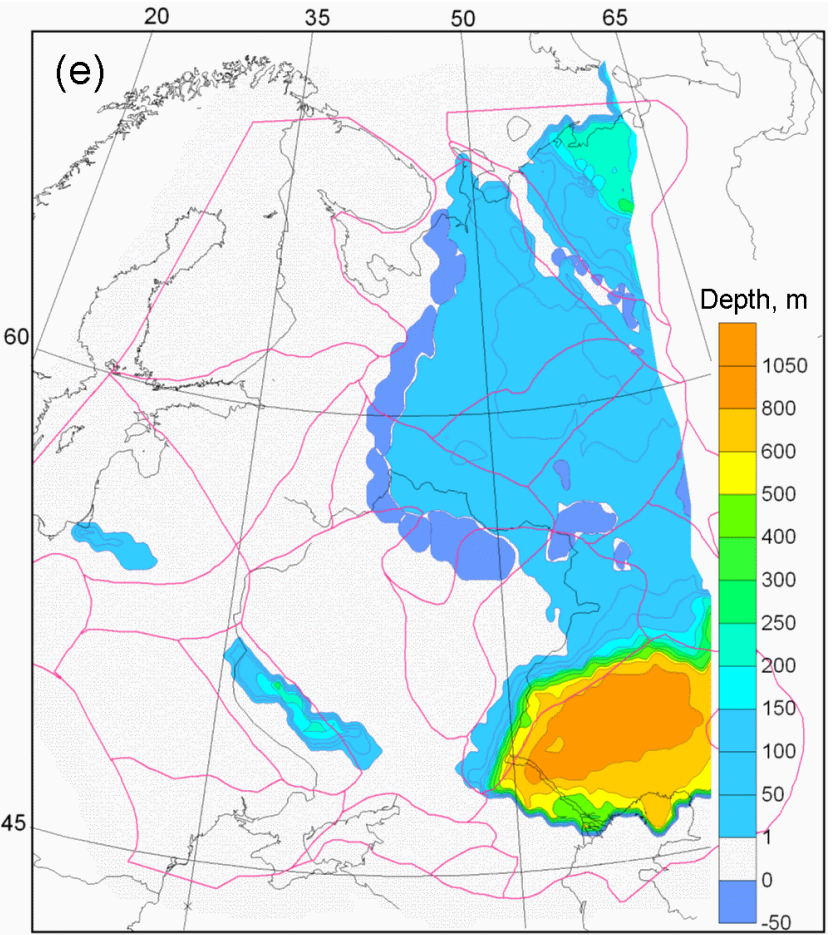

Figure 5. (Continued.)

this time. Moreover, the former basin structure was recovered in $\mathrm{O}_{1}, \mathrm{D}_{1}$, and $\mathrm{K}_{1}$.

[48] The correlation and factor analyses of the five structural EEP maps (Figures 2, 3, 6i, 6j, 6m, and Tables 4 and 5) yielded different results. The direct examination (Table 4) reveals the presence of positive correlations between some structural plans, for example, between the Vendian and the Artinskian stage of the Permian and between the Upper Devonian (the Sartanian horizon of the Frasnian) and the Middle Carboniferous (the Vereyan horizon of the Moscovian). Different results are obtained from the factor analysis, which is a finer method of identifying correlative links (Table 5).

[49] All interrelations are expressed in only two factors, with the contribution of the first factor amounting to $53 \%$, which is a very good result. The first factor implies that the structural plans of the Vendian, Upper Devonian and Middle Carboniferous are closely interrelated. However, the most remarkable inference is that, according to the second factor, a strong correlation exists between the depth to the EEP basement and the top of the Artinskian deposits. This is unexpected because it is generally acknowledged that the main structural features of the EEP sedimentary cover are associated with the basement depth. To fully comprehend these results, similar studies should be performed in relation to inversions in distributions of both thicknesses and structural plans of the EEP sedimentary cover.

[50] Thus, a few variously significant structural reorganizations took place during the formation of the sedimentary cover of the Russian plate from the Riphean to the end of the Paleozoic. Structural plans changed dramatically at the Early Riphean/Late Vendian boundary. At this time, rifting structures (aulacogens) with contrasting amplitudes of downwarping were transformed into flatter platform structures. Accordingly, the Riphean platform was in the state of extension later replaced by platform epeirogeny characterized by different structural and geomorphologic features. However, the main characteristic of the reorganization was the development of inversion processes that commonly did not change the outlines and position of structures. In only a few cases was the position of an anticline crest or the deepest part of a syncline displaced for small lateral distances [Grachev et al., 1994].

[51] The Vendian inversion zones are associated with some Riphean rifts. They are confined to the southern SoligalichYarem rift, the Vyatka rift, and the Oka-Tsna branch of the Ryazan-Saratov rift. As regards the other Riphean structures and their parts, either they had no signatures in the cover structure or negative movements still continues within their areas (e.g. the Kama-Belsk aulacogen). The inversion zones tend to localize near shoulders of Riphean rifts. This is most evident in the Vyatka aulacogen, where Vendian anticlines give way to Devonian synclines within the same area. In the Carboniferous, the inversion took place within the Pechora basin. Here platform anticlines formed along the boundaries of the Devonian Pechora-Kozhva graben and involved even rift areas.

[52] In its southern part, the Laiskaya anticline crosses the central segment of the graben. The Devonian Timanskiy rift is overlain by a Carboniferous-Permian monocline complicated by structural noses and bays [Grachev et al., 1994].

[53] Comparison of the inversion processes reveals a rather wide scatter in time. In some cases, the movements change immediately after the termination of aulacogen development, as is the case, for example, with Vendian anticlines on the Riphean Soligalich-Yarem and Oka-Tsna aulacogens. In other cases, the inversion occurs a few hundred million years later and, moreover, in adjacent areas. This situation took place in the southern Ryazan-Saratov aulacogen, where the southern part of the Oka-Tsna anticline formed in the Devonian after the existence of a vast pre-Devonian uplift encompassing the territory from the Voronezh anteclise to the southern part of the Volga-Urals anteclise [Grachev et al., 1994].

[54] The main structure of the Russian plate cover formed during the Riphean, Vendian to Lower-Middle Paleozoic, and Upper Paleozoic epochs. Vast syneclises mainly developed in later periods.

[55] In addition to the thicknesses, we examined such a parameter as the thickness gradient estimated from the same initial data. The values of the correlation matrix of gradients are given in Table 6 , whereas Table 7 presents the inferred values of the correlation matrix factor loadings. This table gives somewhat different results as compared with the analysis of thicknesses, but similarities between the corresponding factors prevail. For example, the first thickness factor (the greatest loads in $\mathrm{T}_{1-3}$ and $\mathrm{J}_{1-2}$ ) is similar to the second thickness gradient factor (the greatest loads in $\mathrm{T}_{2}-\mathrm{T}_{3}$ and $\left.\mathrm{J}_{1-2}\right)$. The latest Jurassic $\left(\mathrm{J}_{3}\right)$ is also classified as a separate factor uncorrelated with the others. The Cambrian is joined with the Lower Devonian in the same factor. Probably, this might be expected because the thickness gradients are derivatives of thicknesses. 

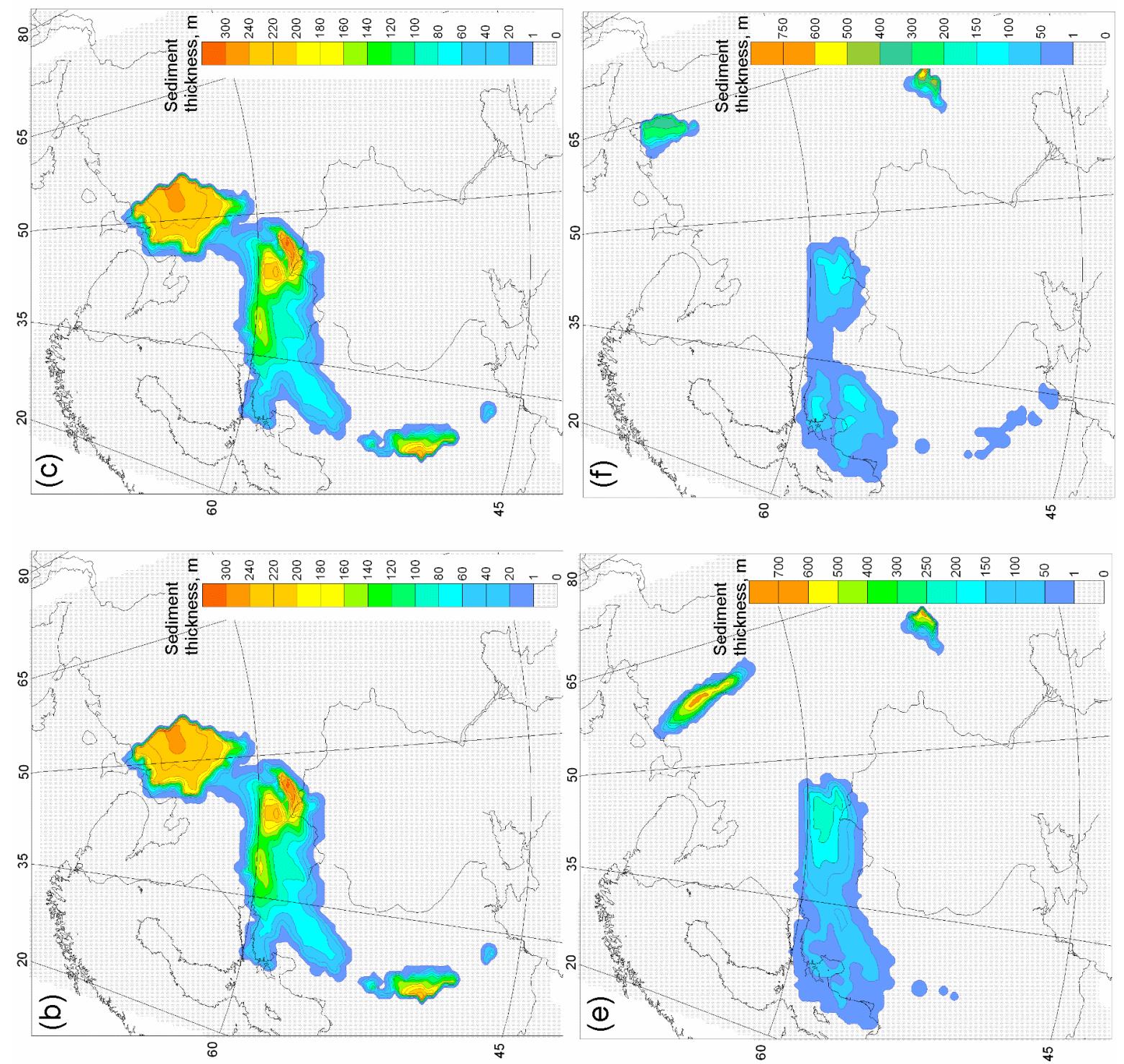

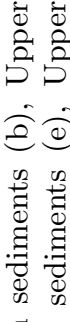

.્త్ .్ㅠ

हี

总苟

क

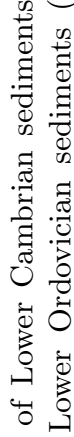
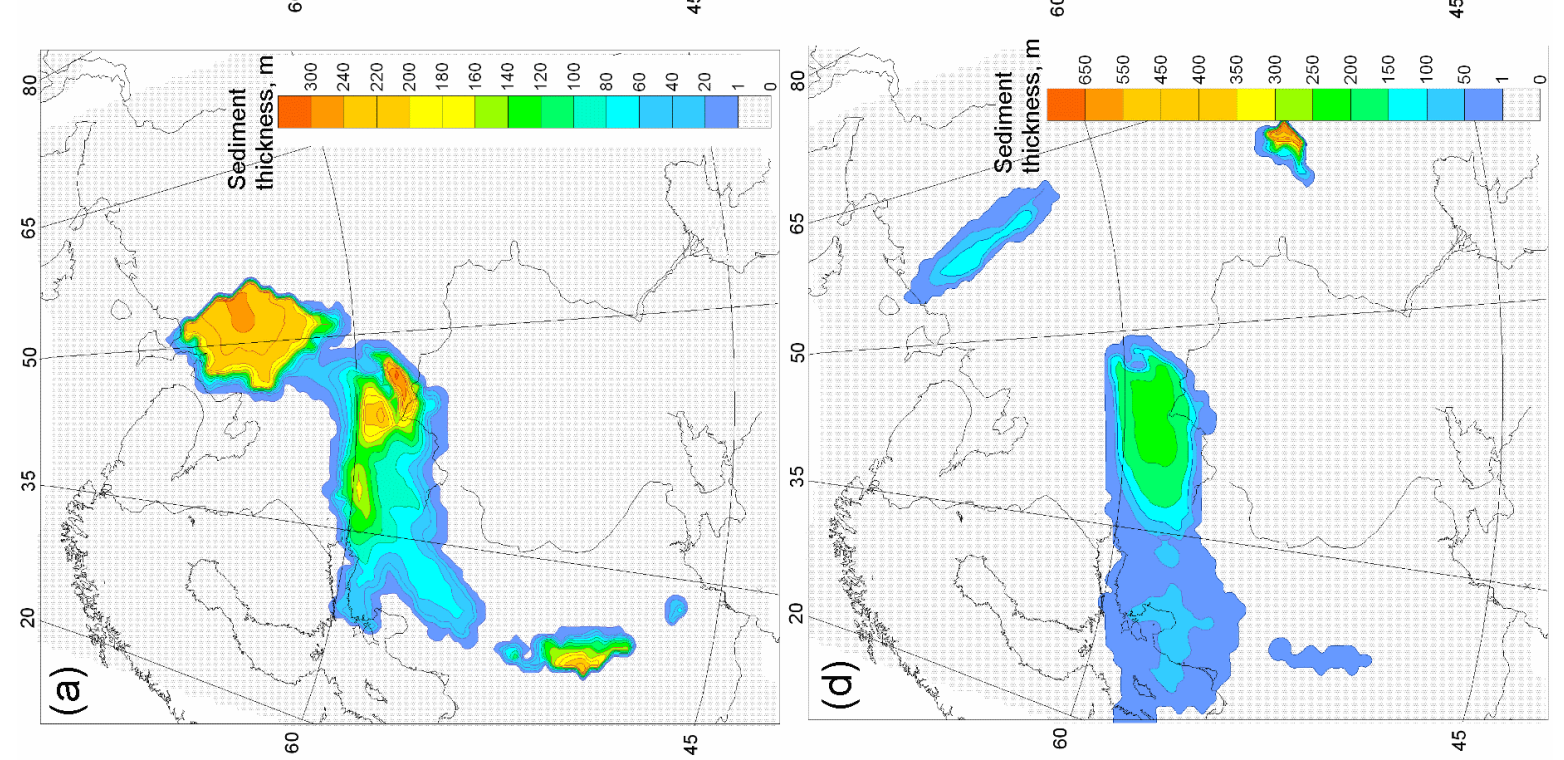

高宇

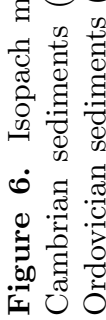



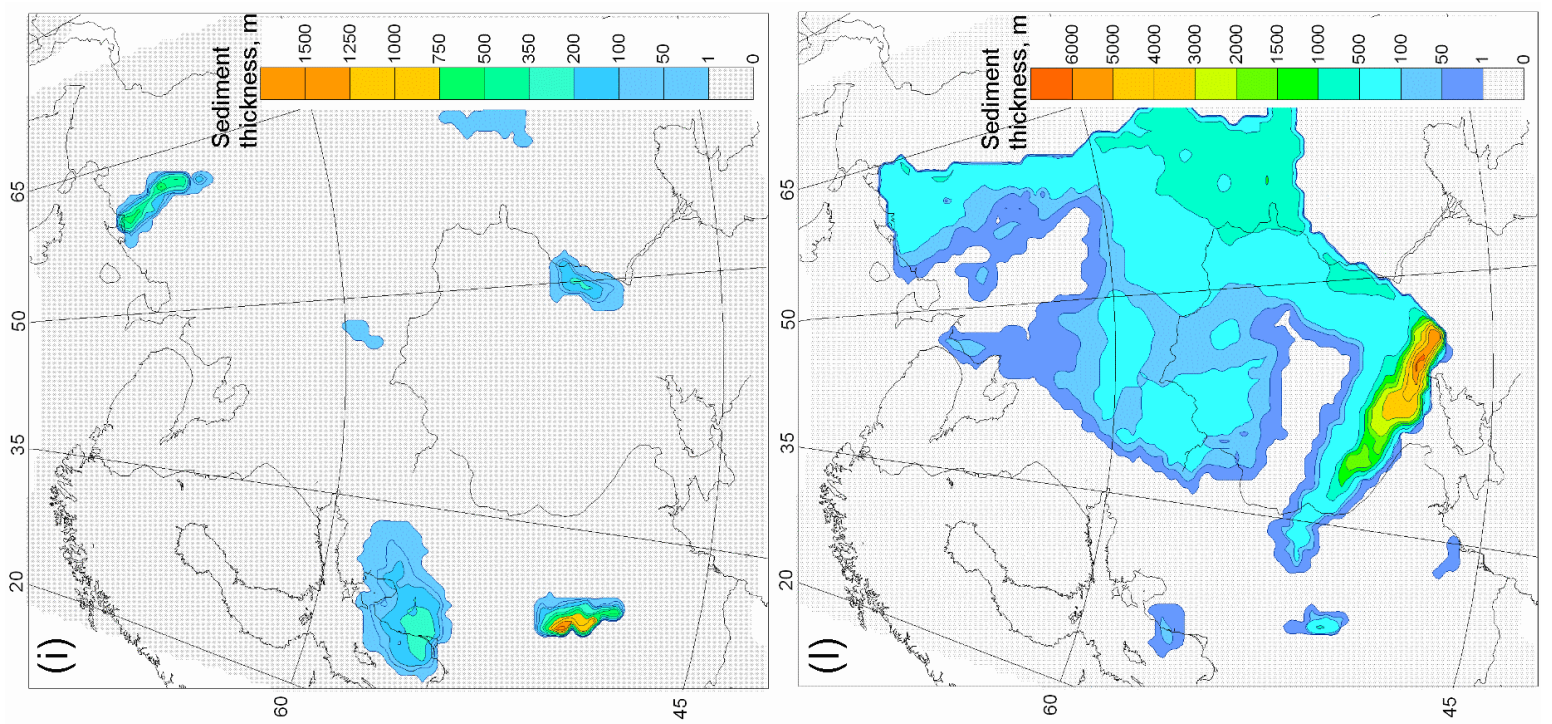

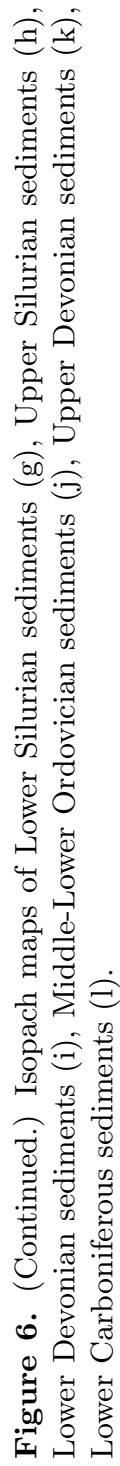
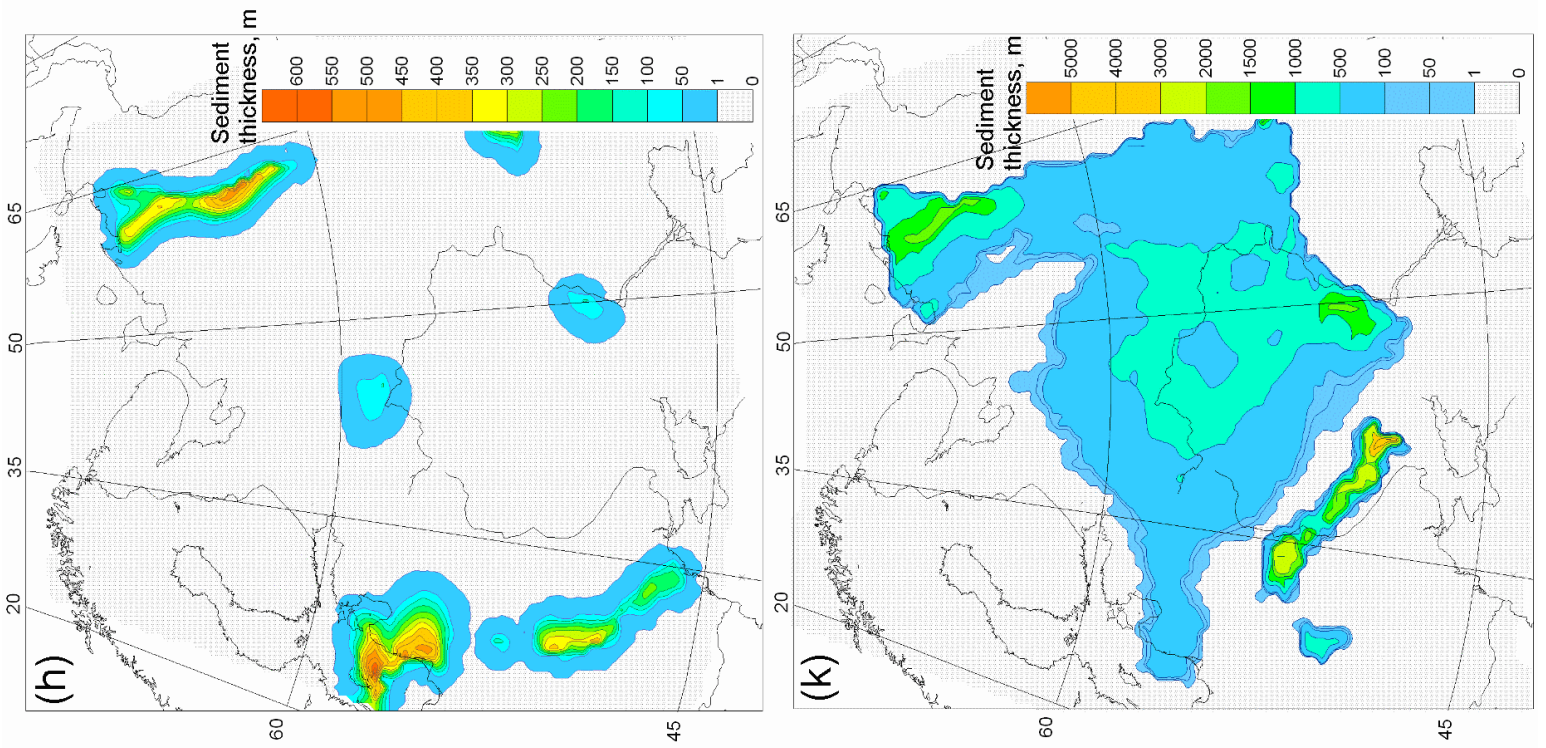

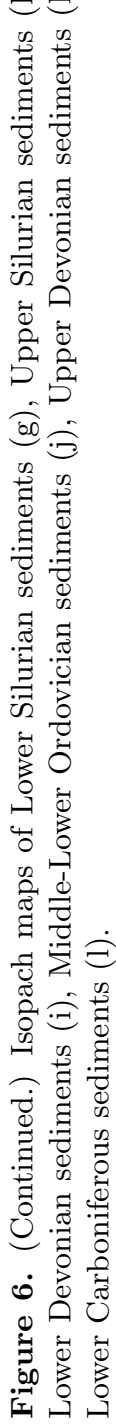
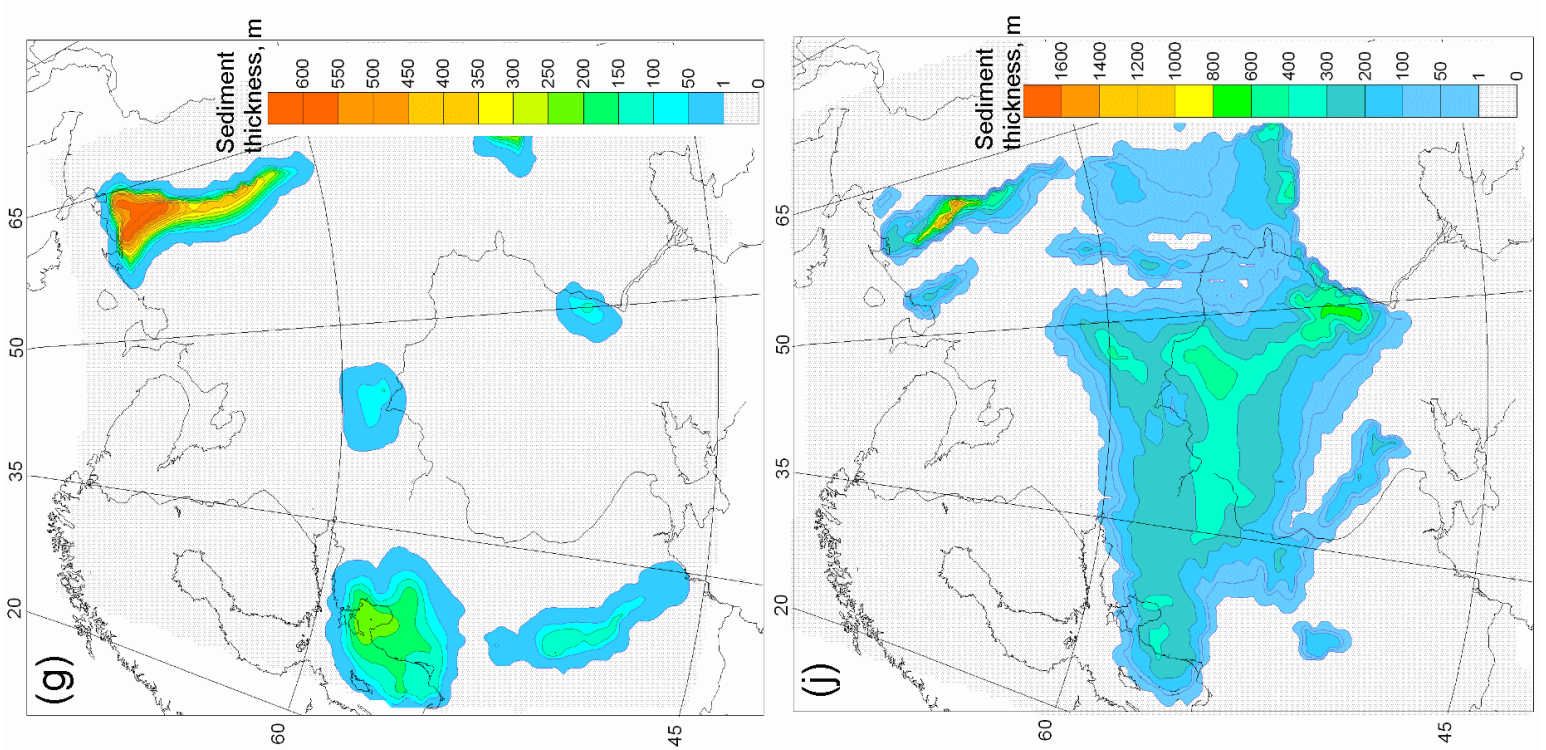

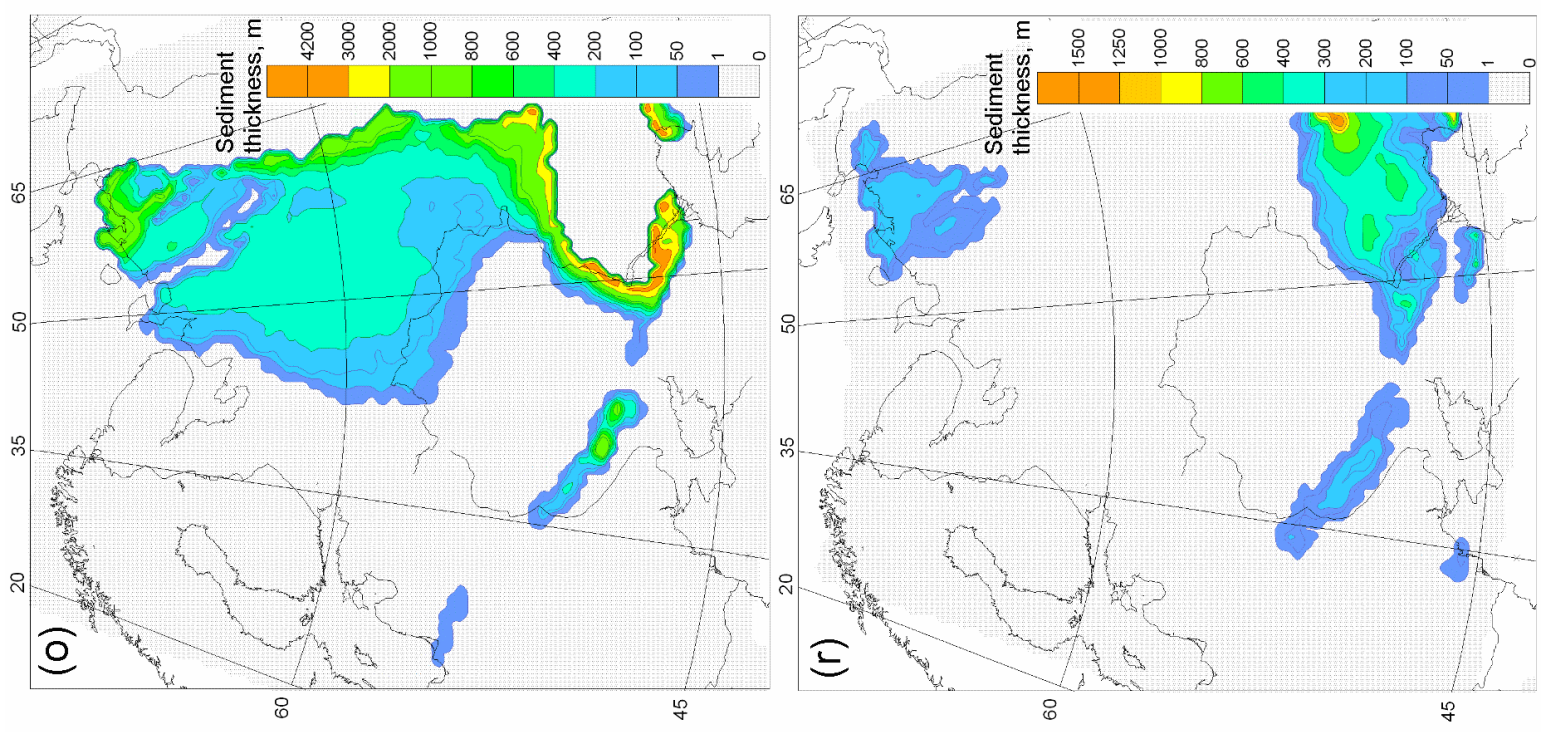

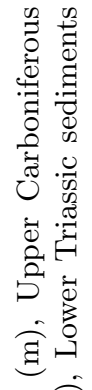
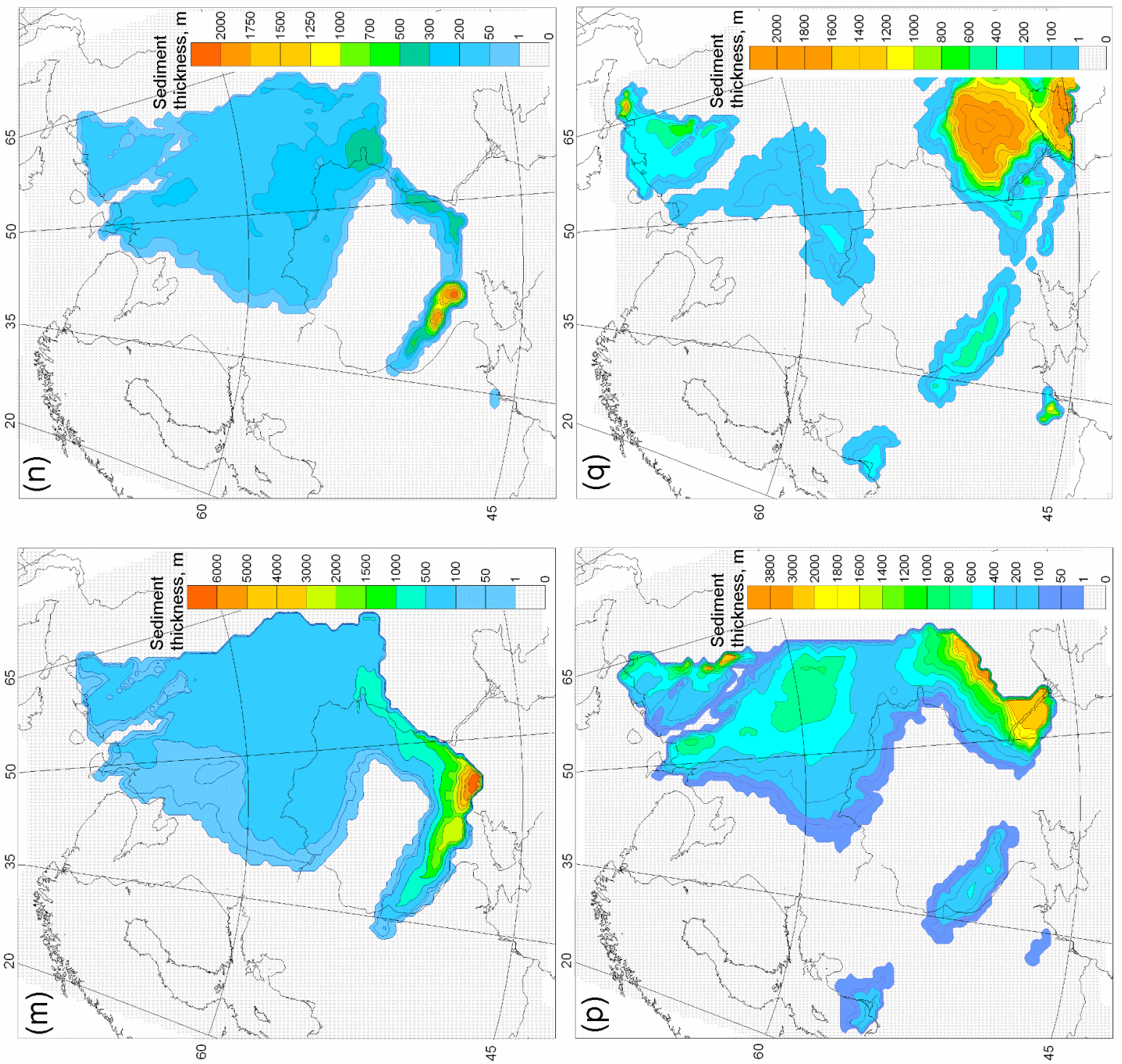

黄

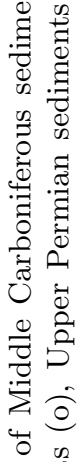

范 :

㐘

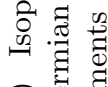

ت્屯

苛

吾

已

0 용

范

正 

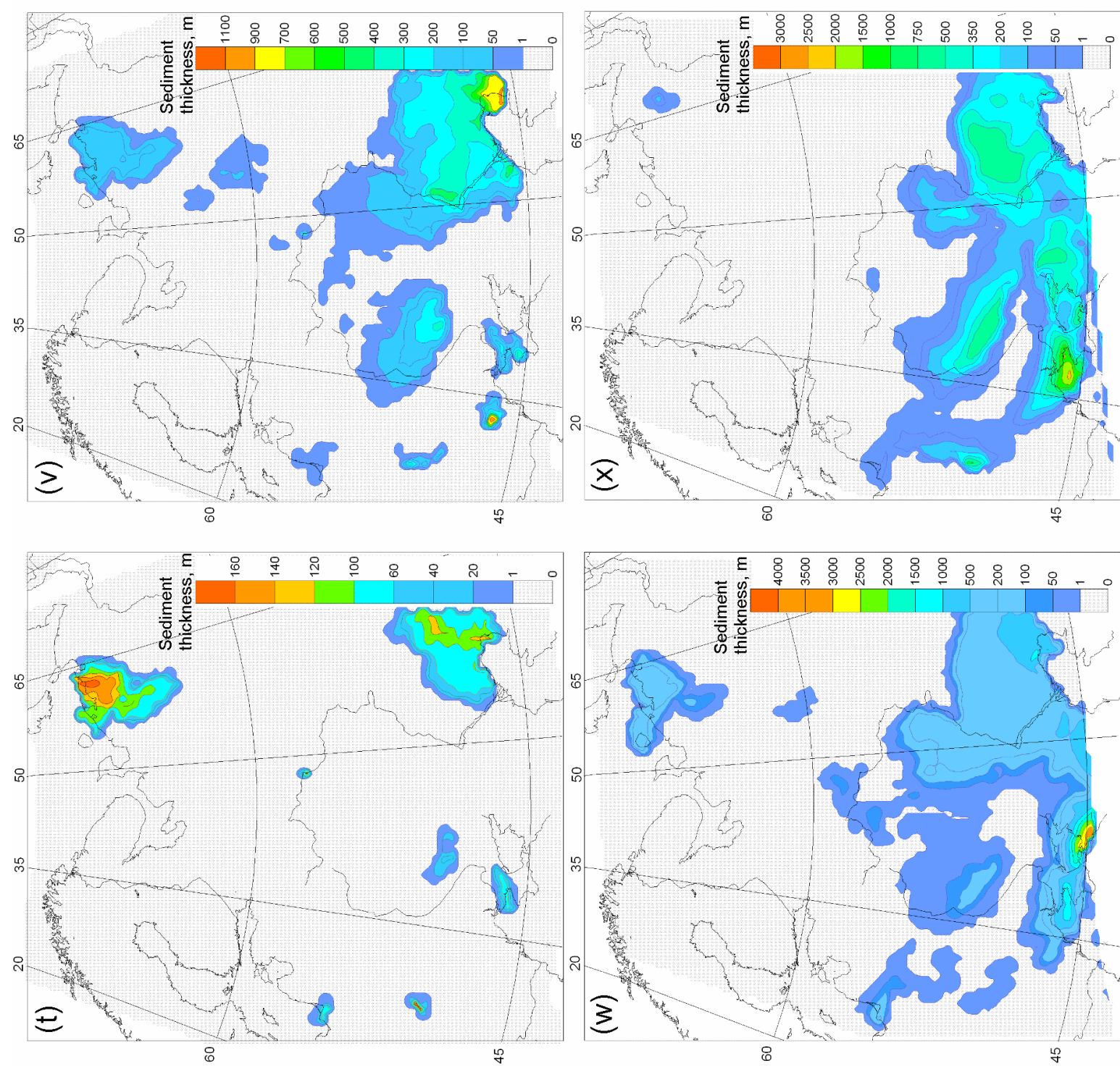

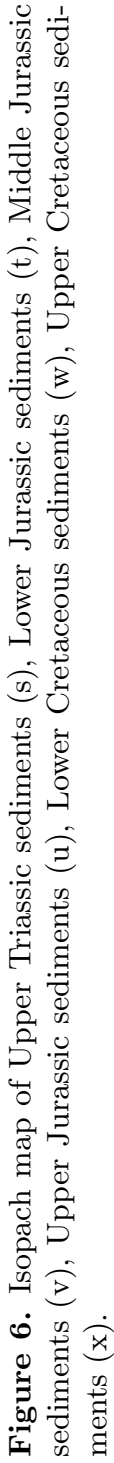
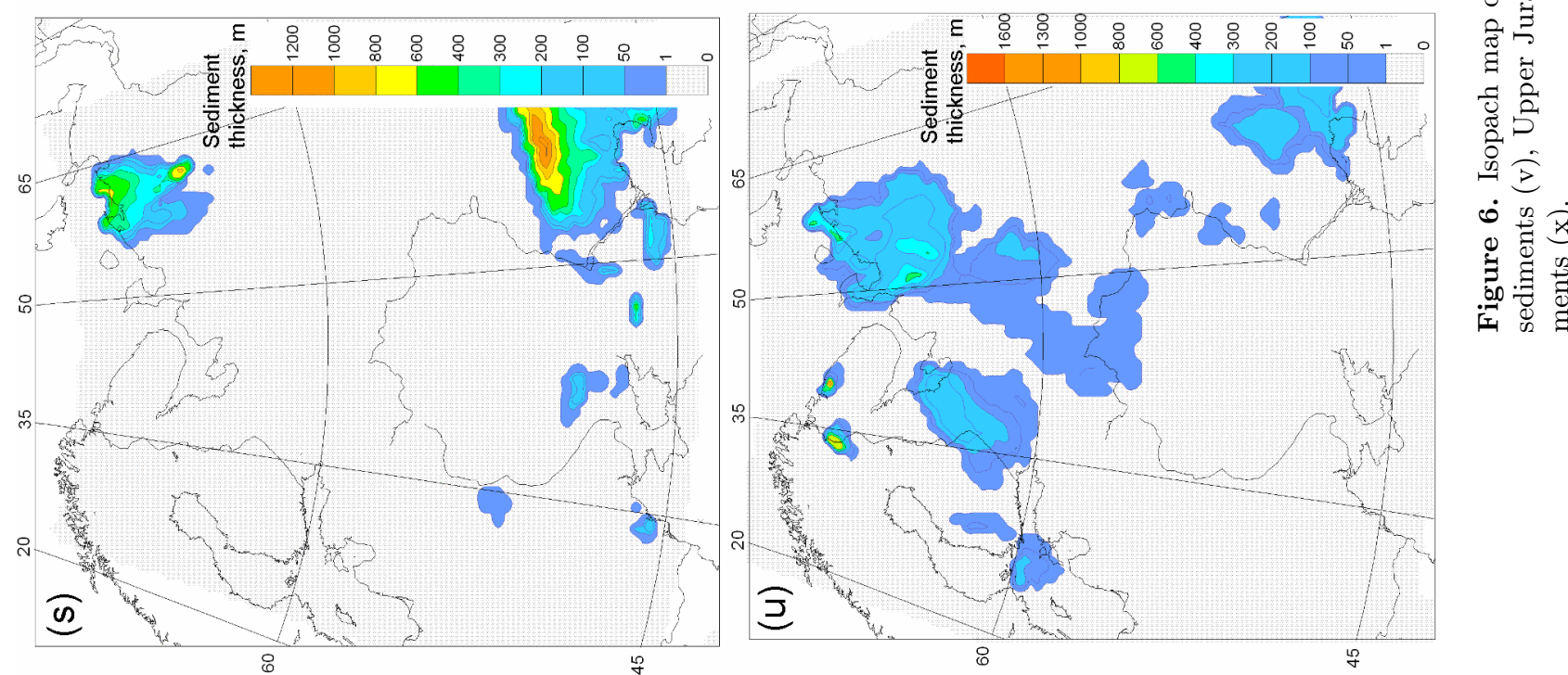


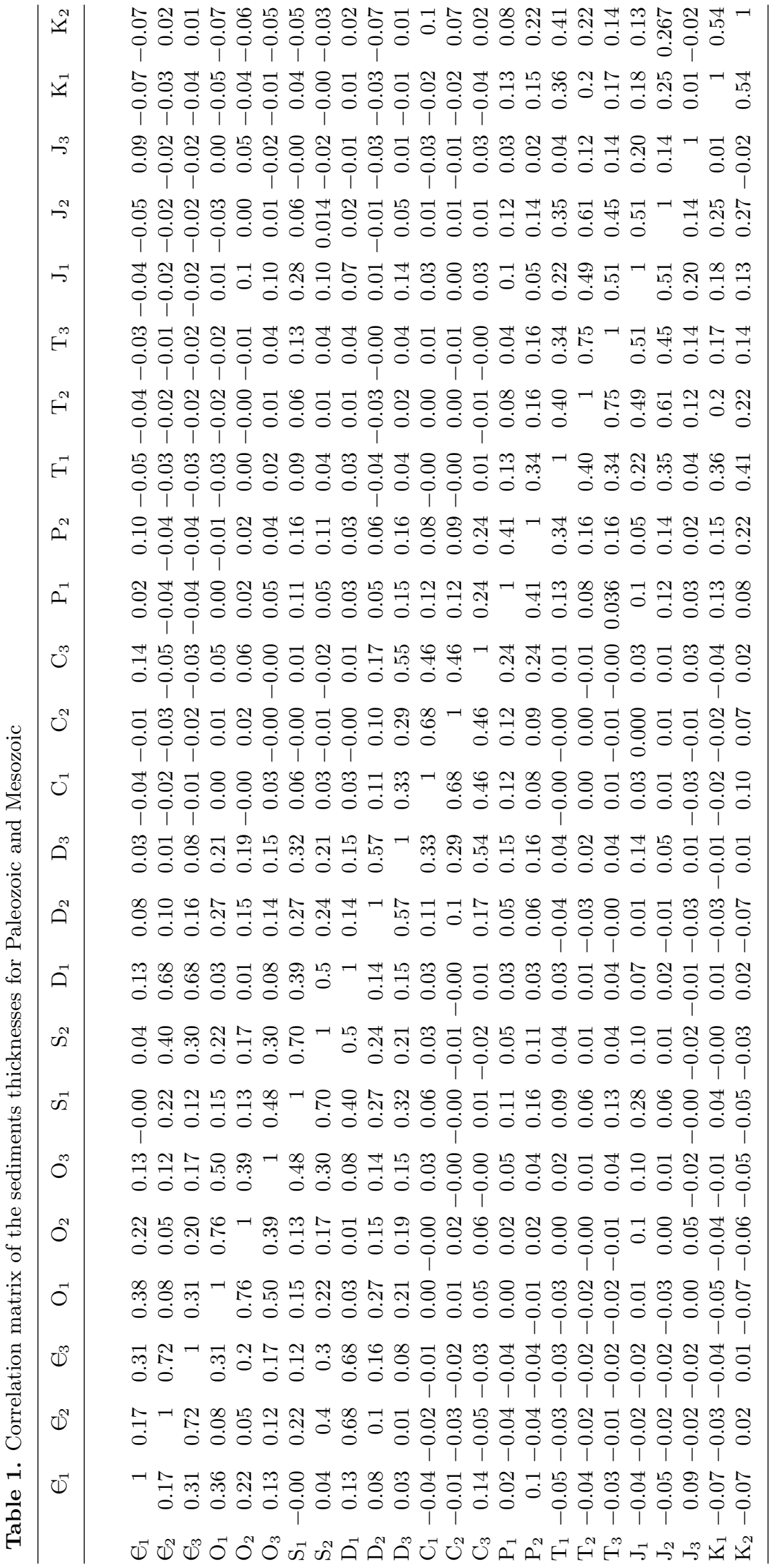


Table 2. Factor loadings of the sediments thicknesses for Paleozoic and Mesozoic

\begin{tabular}{|c|c|c|c|c|c|c|c|c|}
\hline & \multicolumn{8}{|c|}{ Factors } \\
\hline & 1 & 2 & 3 & 4 & 5 & 6 & 7 & 8 \\
\hline $\mathrm{e}_{1}$ & -0.01 & 0.348 & 0.459 & -0.04 & -0.283 & 0.03 & 0.227 & 0.319 \\
\hline $\mathrm{e}_{2}$ & -0.03 & 0.878 & 0.00 & -0.02 & 0.140 & -0.02 & -0.04 & -0.02 \\
\hline$e_{3}$ & -0.02 & 0.878 & 0.236 & -0.01 & -0.02 & 0.05 & -0.05 & -0.01 \\
\hline $\mathrm{O}_{1}$ & -0.04 & 0.09 & 0.912 & -0.01 & 0.02 & 0.163 & -0.02 & -0.02 \\
\hline $\mathrm{O}_{2}$ & 0.03 & 0.03 & 0.847 & 0.02 & 0.02 & 0.08 & -0.04 & 0.08 \\
\hline $\mathrm{O}_{3}$ & -0.00 & 0.01 & 0.615 & 0.02 & 0.524 & -0.06 & 0.03 & -0.107 \\
\hline $\mathrm{S}_{1}$ & 0.114 & 0.159 & 0.09 & -0.04 & 0.872 & 0.181 & 0.103 & 0.01 \\
\hline $\mathrm{S}_{2}$ & 0.01 & 0.395 & 0.09 & -0.03 & 0.715 & 0.137 & 0.08 & -0.04 \\
\hline $\mathrm{D}_{1}$ & 0.05 & 0.840 & -0.100 & 0.02 & 0.300 & 0.08 & 0.01 & 0.02 \\
\hline $\mathrm{D}_{2}$ & -0.05 & 0.02 & 0.126 & -0.01 & 0.113 & 0.867 & -0.01 & -0.08 \\
\hline $\mathrm{D}_{3}$ & 0.05 & 0.01 & 0.104 & 0.348 & 0.172 & 0.801 & 0.101 & 0.04 \\
\hline $\mathrm{C}_{1}$ & 0.00 & 0.00 & -0.01 & 0.886 & 0.05 & 0.05 & 0.01 & -0.07 \\
\hline $\mathrm{C}_{2}$ & -0.01 & -0.03 & 0.01 & 0.882 & -0.02 & 0.02 & 0.02 & -0.04 \\
\hline $\mathrm{C}_{3}$ & -0.02 & -0.01 & 0.02 & 0.633 & -0.115 & 0.371 & 0.314 & 0.161 \\
\hline $\mathrm{P}_{1}$ & 0.01 & -0.04 & -0.01 & 0.114 & 0.107 & -0.01 & 0.791 & 0.03 \\
\hline $\mathrm{P}_{2}$ & 0.248 & -0.01 & -0.01 & 0.01 & 0.03 & 0.07 & 0.783 & -0.02 \\
\hline $\mathrm{T}_{1}$ & 0.806 & -0.01 & -0.01 & -0.01 & -0.01 & -0.01 & 0.128 & -0.02 \\
\hline $\mathrm{T}_{2}$ & 0.850 & -0.01 & -0.02 & 0.01 & 0.01 & -0.02 & 0.04 & 0.07 \\
\hline $\mathrm{T}_{3}$ & 0.795 & -0.01 & -0.05 & -0.02 & 0.161 & 0.01 & -0.02 & 0.205 \\
\hline $\mathrm{J}_{1}$ & 0.667 & -0.06 & 0.01 & 0.04 & 0.382 & 0.05 & -0.02 & 0.258 \\
\hline $\mathrm{J}_{2}$ & 0.766 & -0.01 & -0.01 & 0.01 & -0.02 & 0.01 & 0.191 & -0.101 \\
\hline $\mathrm{J}_{3}$ & 0.169 & 0.01 & 0.06 & -0.02 & -0.107 & -0.06 & 0.06 & 0.714 \\
\hline $\mathrm{K}_{1}$ & 0.569 & 0.01 & 0.01 & -0.06 & -0.02 & -0.01 & 0.117 & -0.427 \\
\hline $\mathrm{K}_{2}$ & 0.564 & 0.1 & -0.01 & 0.01 & -0.222 & -0.06 & 0.123 & -0.517 \\
\hline
\end{tabular}

Table 3. Factor loadings of gradients of the sediments thicknesses for Paleozoic and Mesozoic

\begin{tabular}{|c|c|c|c|c|c|c|c|c|}
\hline & \multicolumn{8}{|c|}{ Factors } \\
\hline & 1 & 2 & 3 & 4 & 5 & 6 & 7 & 8 \\
\hline $\mathrm{E}_{1}$ & 0.513 & 0.02 & 0.285 & -0.200 & 0.01 & -0.02 & 0.01 & 0.307 \\
\hline $\mathrm{e}_{2}$ & 0.887 & 0.01 & 0.01 & 0.02 & 0.01 & 0.01 & 0.01 & -0.02 \\
\hline $\mathrm{e}_{3}$ & 0.918 & 0.01 & 0.01 & 0.02 & 0.01 & -0.02 & 0.01 & 0.01 \\
\hline $\mathrm{O}_{1}$ & 0.02 & 0.01 & 0.910 & 0.01 & 0.01 & 0.02 & 0.01 & -0.02 \\
\hline $\mathrm{O}_{2}$ & 0.01 & 0.01 & 0.849 & 0.02 & 0.01 & 0.01 & 0.02 & 0.01 \\
\hline $\mathrm{O}_{3}$ & 0.01 & 0.02 & 0.708 & 0.346 & 0.01 & 0.01 & -0.02 & 0.01 \\
\hline $\mathrm{S}_{1}$ & 0.02 & 0.02 & 0.239 & 0.799 & 0.01 & 0.02 & 0.01 & 0.01 \\
\hline $\mathrm{S}_{2}$ & 0.350 & 0.01 & 0.276 & 0.676 & 0.01 & 0.01 & 0.02 & -0.02 \\
\hline $\mathrm{D}_{1}$ & 0.822 & 0.02 & -0.02 & 0.343 & 0.02 & 0.02 & 0.01 & -0.02 \\
\hline $\mathrm{D}_{2}$ & 0.01 & 0.02 & 0.01 & 0.667 & 0.02 & 0.234 & 0.01 & 0.186 \\
\hline $\mathrm{D}_{3}$ & -0.02 & 0 & 0.01 & 0.507 & 0.509 & 0.02 & 0 & 0.335 \\
\hline $\mathrm{C}_{1}$ & 0.01 & 0.01 & 0.02 & 0.01 & 0.832 & -0.02 & 0.02 & 0.01 \\
\hline $\mathrm{C}_{2}$ & 0.02 & -0.02 & 0.02 & 0.01 & 0.832 & 0.02 & 0.01 & -0.02 \\
\hline $\mathrm{C}_{3}$ & 0.02 & 0.01 & -0.02 & 0.01 & 0.670 & 0.223 & -0.02 & 0.345 \\
\hline $\mathrm{P}_{1}$ & -0.02 & 0.01 & -0.02 & 0.01 & 0.01 & 0.727 & -0.02 & 0.01 \\
\hline $\mathrm{P}_{2}$ & 0.01 & 0.228 & -0.02 & 0.01 & 0.02 & 0.682 & -0.02 & 0.02 \\
\hline $\mathrm{T}_{1}$ & 0.01 & 0.268 & 0.01 & -0.03 & -0.03 & 0.654 & 0.204 & 0.01 \\
\hline $\mathrm{T}_{2}$ & -0.03 & 0.834 & 0.01 & -0.03 & 0.01 & 0.293 & -0.03 & 0.01 \\
\hline $\mathrm{T}_{3}$ & 0.01 & 0.851 & -0.03 & 0.01 & 0.01 & 0.137 & -0.03 & 0.01 \\
\hline $\mathrm{J}_{1}$ & -0.03 & 0.724 & 0.01 & 0.235 & 0.01 & 0.01 & 0.208 & -0.03 \\
\hline $\mathrm{J}_{2}$ & 0.01 & 0.620 & 0.01 & -0.03 & 0.01 & 0.389 & 0.285 & 0.01 \\
\hline $\mathrm{J}_{3}$ & -0.03 & 0.197 & -0.03 & 0.01 & 0.01 & -0.03 & -0.03 & 0.738 \\
\hline $\mathrm{K}_{1}$ & 0.01 & -0.03 & -0.03 & -0.03 & -0.03 & 0.01 & 0.863 & -0.03 \\
\hline $\mathrm{K}_{2}$ & 0.01 & -0.03 & -0.03 & 0.01 & 0.217 & -0.03 & 0.808 & 0.01 \\
\hline
\end{tabular}



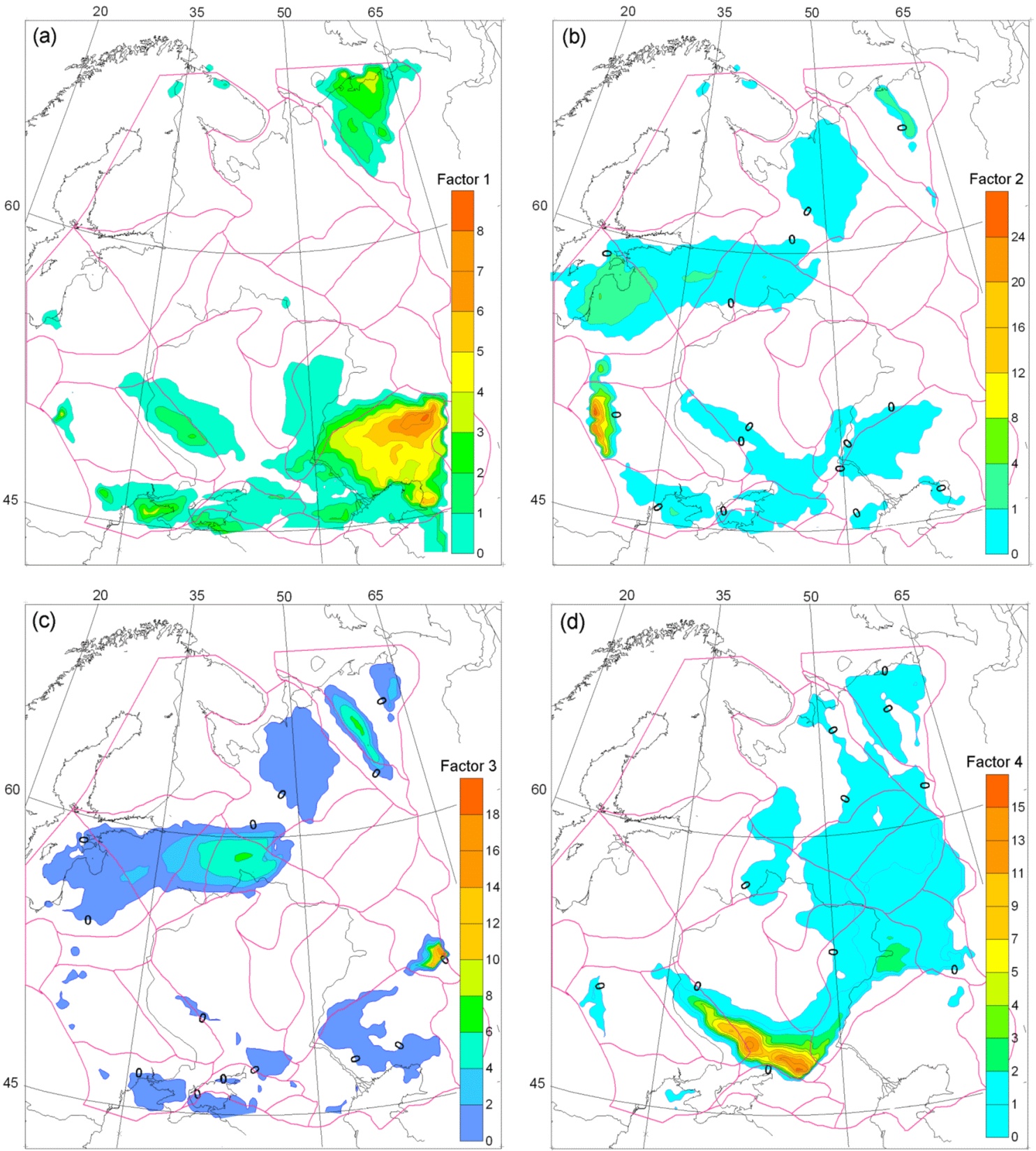

Figure 7. Maps the factors: (a) 1st factor, $\mathrm{T}_{1-3}, \mathrm{~J}_{1-2}, \mathrm{~K}_{1-2}$; (b) $2 \mathrm{~d}$ factor, $\mathrm{E}_{2-3}$, $\mathrm{D}_{1}$; (c) $3 \mathrm{~d}$ factor, $\mathrm{E}_{1}$, $\mathrm{O}_{1}, \mathrm{O}_{2}, \mathrm{O}_{3} ;$ (d) 4th factor, $\mathrm{C}_{1}, \mathrm{C}_{2}, \mathrm{C}_{3}$. 

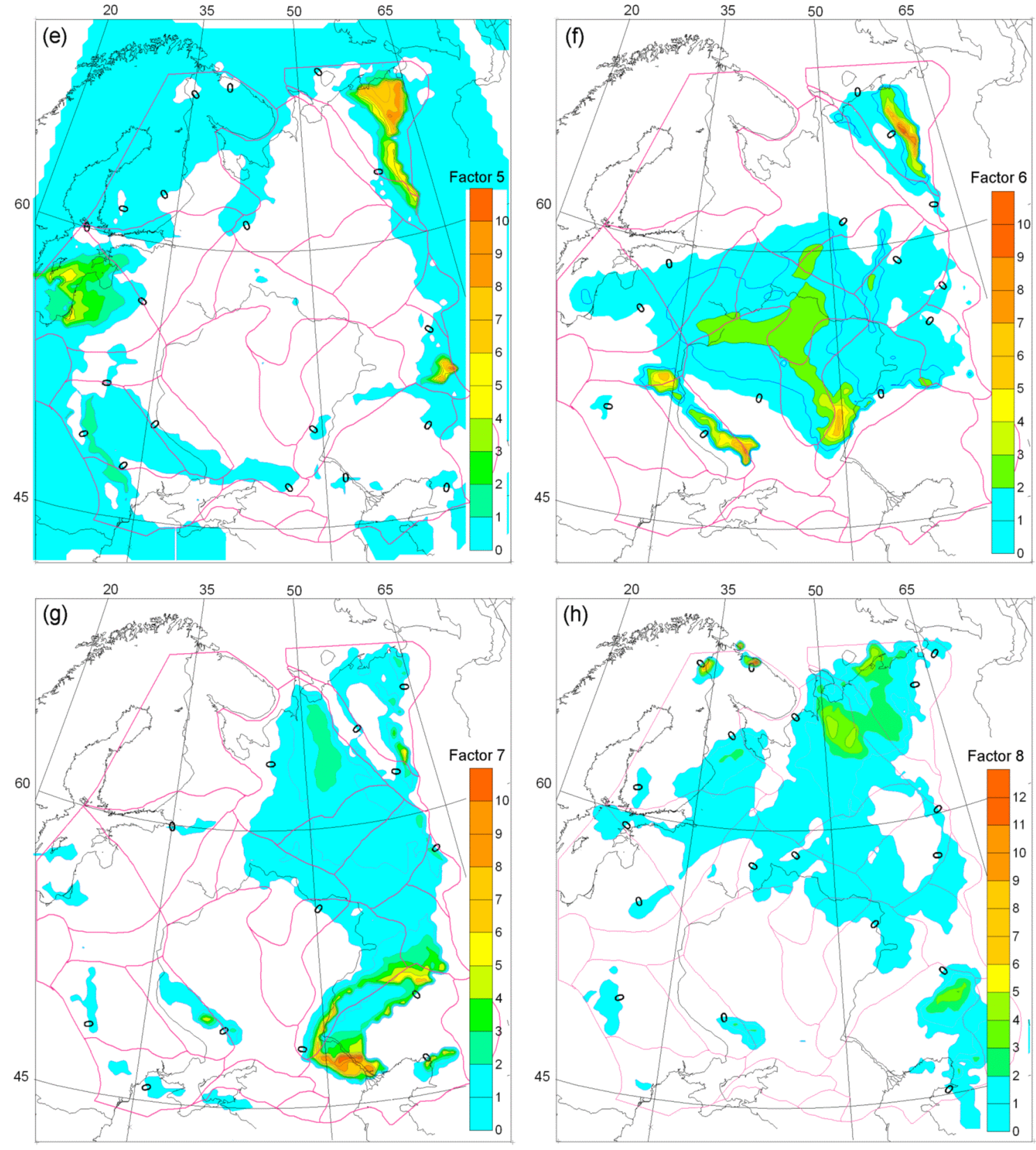

Figure 7. (Continued.) (e) 5th factor, $\mathrm{S}_{1}-\mathrm{S}_{2}$; (f) 6th factor, $\mathrm{D}_{2}-\mathrm{D}_{3}$; (g) 7th factor, $\mathrm{P}_{1}-\mathrm{P}_{2}$; (h) 8th factor, $\mathrm{J}_{3}$. 
Table 4. Correlation matrix of the selected structural maps of East European platform

\begin{tabular}{crrrrr}
\hline & Basement & $\mathrm{V}$ & $\mathrm{D}_{3 \mathrm{sr}}$ & $\mathrm{C}_{2 \mathrm{vr}}$ & $\mathrm{P}_{1 \mathrm{ar}}$ \\
\hline Basement & 1 & 0.441 & 0.348 & 0.386 & 0.562 \\
$\mathrm{~V}$ & 0.441 & 1 & 0.410 & 0.583 & 0.052 \\
$\mathrm{D}_{3 \mathrm{sr}}$ & 0.348 & 0.410 & 1 & 0.717 & 0.108 \\
$\mathrm{C}_{2 \mathrm{vr}}$ & 0.386 & 0.583 & 0.717 & 1 & 0.091 \\
$\mathrm{P}_{1 \mathrm{ar}}$ & 0.562 & 0.052 & 0.108 & 0.091 & 1 \\
\hline
\end{tabular}

Table 5. Factor loadings of the 5 structural maps of the East European platform

\begin{tabular}{crr}
\hline & \multicolumn{2}{c}{ Factor } \\
\hline & $1(53 \%)$ & $2(25 \%)$ \\
\hline Basement & 0.405 & 0.799 \\
$\mathrm{~V}$ & 0.766 & 0.141 \\
$\mathrm{D}_{3 \mathrm{sr}}$ & 0.830 & 0.09 \\
$\mathrm{C}_{2 \mathrm{vr}}$ & 0.905 & 0.09 \\
$\mathrm{P}_{1 \mathrm{ar}}$ & -0.05 & 0.930 \\
\hline
\end{tabular}

\section{Conclusion}

[56] The comparative analysis of the development of structure, sedimentation, and magmatism during late Proterozoic through Paleozoic history of East European platform evidently shows that all these processes were obviously connected. Excluding magmatism, the character of this relationship was outlined by N. S. Shatsky. Its nature was understood later when it became clear that aulacogens have riftogenic provenance [Grachev and Fedorovsky, 1970], while syneclises or sedimentary basins correspond to the post-rift stage (the Shatsky's rule) [Grachev, 1987].

[57] Each of three depicted characteristics numerously changed through time. Nevertheless, main turning-points in the history of the platform development could be distinguished viacoincidence in time of all three processes. There are three prominent turning-points and each of them were comparatively short in geological sense. At the Riphean to Vendian boundary sharp change in structural plans and geodynamic setting occurred. It correlates with increase in the area of sea basins and change in sedimentary environment. Intensive domi-nantly tholeiitic magmatism also ceased at this time. The next large reconstruction in structural plan occurred between early and middle Devonian. This period is characterized by decrease in marine basin area and by repetition of alkaline-basaltic magmatic activity. Finally, at the end of Permian the formation of sharp structural forms ceased. Territory of the platform was highly uplifted. Sedimentation rates decreased.

[58] It is possible that conclusions of some authors about the correlation of large turning-points in the platform with events in surrounding paleooceanic areas are true. Event at Riphean to Vendian boundary coincides with opening of the Japetus ocean. Events at early and middle Devonian coincide with the opening of the Paleo-Uralian ocean. The turning-point at the end of Permian was possibly caused by the closing of the Paleo-Uralian ocean. Basing on this point of view the platform development was understood by Khain [1986] (from general positions), by Aparin et al. [1988] (from positions of sedimentary formations in East European platform) and others. At the same time it is difficult to make nowadays simple correlation of events in the platform and adjacent areas because the interference of processes in neighboring areas occurred within the platform (ex.: closing of Japetus and opening of the Paleo-Uralian oceans). This interpretation was complicated by intraplate processes.

[59] As in other platforms development of magmatism within East European platform was connected with changes in thermal conditions in the upper mantle during aulacogen or rift stage of development. Two types of magmatism development could be distinguished according to the character of development of structure and sedimentary formations. The first one is the pre-rift type (part of the Baltic shield in the Late Proterozoic), when lava fields covered large territories without structural speciality. The second one is the rift type. But even in this case magmatism took place not only in rifts but abroad.

[60] Thus, an important conclusion could be made on the basis of East European platform example. This is the conclusion about the absence of platform volcanism as a specific type. Another conclusion is that the Late Pre-Cambrian riftogenic stage within East European platform was the most active.

[61] The area covered by aulacogens and volumes of sedimentary and volcano-plutonic complexes according to preliminary calculations were significantly larger than in the Middle Paleozoic. Tectonic activity if all three parameters are taken together seem to decrease from the Riphean to Mesozoic through Cenozoic.

[62] Studying the development of sedimentary formations it is impossible to ignore the influence of processes on active margins (Scandinavian and Uralian) on the development of sedimentary basins both immediately adjacent to them and located in hundreds of kilometers afar.

[63] Acknowledgments. This study financially supported by Program 5 "Interaction of a Mantle Plume with the Lithosphere" of the Division of Earth Sciences, Russian Academy of Sciences, and Grant RSH-1901.2003.5 from the President of the Russian Federation for support of research schools and Grant 030564303 of the Russian Basic Research Foundation. 


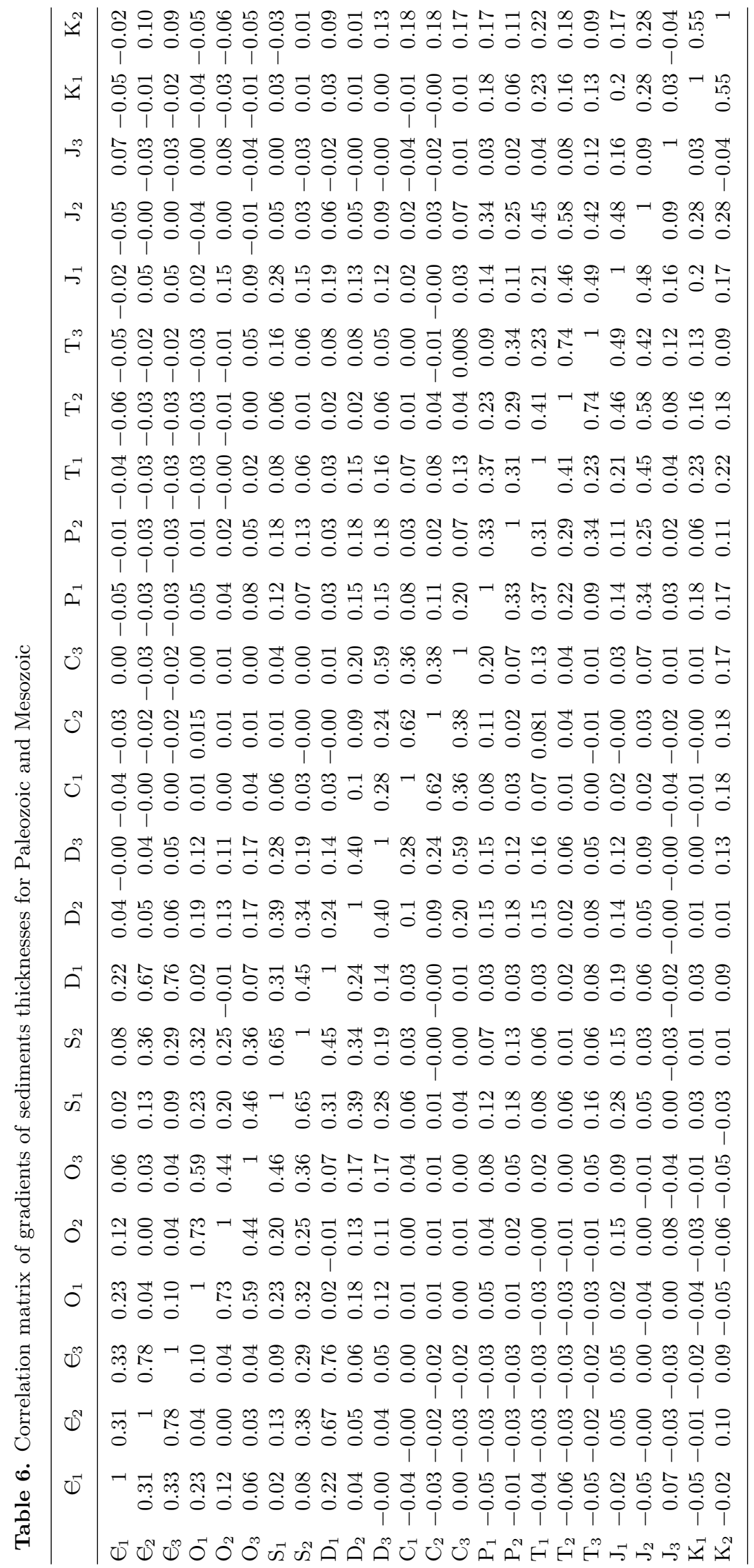


Table 7. Factor loadings of gradients of sediments thicknesses for Paleozoic and Mesozoic

\begin{tabular}{|c|c|c|c|c|c|c|c|c|}
\hline & \multicolumn{8}{|c|}{ Factors } \\
\hline & 1 & 2 & 3 & 4 & 5 & 6 & 7 & 8 \\
\hline $\mathrm{C}_{1}$ & 0.513 & 0.02 & 0.285 & -0.200 & 0.01 & -0.02 & 0.01 & 0.307 \\
\hline $\mathrm{E}_{2}$ & 0.887 & 0.01 & 0.01 & 0.02 & 0.01 & 0.01 & 0.01 & -0.02 \\
\hline $\mathrm{e}_{3}$ & 0.918 & 0.01 & 0.01 & 0.02 & 0.01 & -0.02 & 0.01 & 0.01 \\
\hline $\mathrm{O}_{1}$ & 0.02 & 0.01 & 0.910 & 0.01 & 0.01 & 0.02 & 0.01 & -0.02 \\
\hline $\mathrm{O}_{2}$ & 0.01 & 0.01 & 0.849 & 0.02 & 0.01 & 0.01 & 0.02 & 0.01 \\
\hline $\mathrm{O}_{3}$ & 0.01 & 0.02 & 0.708 & 0.346 & 0.01 & 0.01 & -0.02 & 0.01 \\
\hline $\mathrm{S}_{1}$ & 0.02 & 0.02 & 0.239 & 0.799 & 0.01 & 0.02 & 0.01 & 0.01 \\
\hline $\mathrm{S}_{2}$ & 0.350 & 0.01 & 0.276 & 0.676 & 0.01 & 0.01 & 0.02 & -0.02 \\
\hline $\mathrm{D}_{1}$ & 0.822 & 0.02 & -0.02 & 0.343 & 0.02 & 0.02 & 0.01 & -0.02 \\
\hline $\mathrm{D}_{2}$ & 0.01 & 0.02 & 0.01 & 0.667 & 0.02 & 0.234 & 0.01 & 0.186 \\
\hline $\mathrm{D}_{3}$ & -0.02 & 0 & 0.01 & 0.507 & 0.509 & 0.02 & 0 & 0.335 \\
\hline $\mathrm{C}_{1}$ & 0.01 & 0.01 & 0.02 & 0.01 & 0.832 & -0.02 & 0.02 & 0.01 \\
\hline $\mathrm{C}_{2}$ & 0.02 & -0.02 & 0.02 & 0.01 & 0.832 & 0.02 & 0.01 & -0.02 \\
\hline $\mathrm{C}_{3}$ & 0.02 & 0.01 & -0.02 & 0.01 & 0.670 & 0.223 & -0.02 & 0.345 \\
\hline $\mathrm{P}_{1}$ & -0.02 & 0.01 & -0.02 & 0.01 & 0.01 & 0.727 & -0.02 & 0.01 \\
\hline $\mathrm{P}_{2}$ & 0.01 & 0.228 & -0.02 & 0.01 & 0.02 & 0.682 & -0.02 & 0.02 \\
\hline $\mathrm{T}_{1}$ & 0.01 & 0.268 & 0.01 & -0.03 & -0.03 & 0.654 & 0.204 & 0.01 \\
\hline $\mathrm{T}_{2}$ & -0.03 & 0.834 & 0.01 & -0.03 & 0.01 & 0.293 & -0.03 & 0.01 \\
\hline $\mathrm{T}_{3}$ & 0.01 & 0.851 & -0.03 & 0.01 & 0.01 & 0.137 & -0.03 & 0.01 \\
\hline $\mathrm{J}_{1}$ & -0.03 & 0.724 & 0.01 & 0.235 & 0.01 & 0.01 & 0.208 & -0.03 \\
\hline $\mathrm{J}_{2}$ & 0.01 & 0.620 & 0.01 & -0.03 & 0.01 & 0.389 & 0.285 & 0.01 \\
\hline $\mathrm{J}_{3}$ & -0.03 & 0.197 & -0.03 & 0.01 & 0.01 & -0.03 & -0.03 & 0.738 \\
\hline $\mathrm{K}_{1}$ & 0.01 & -0.03 & -0.03 & -0.03 & -0.03 & 0.01 & 0.863 & -0.03 \\
\hline $\mathrm{K}_{2}$ & 0.01 & -0.03 & -0.03 & 0.01 & 0.217 & -0.03 & 0.808 & 0.01 \\
\hline
\end{tabular}

\section{References}

Aparin, V. P., I. I. Abramovsky, and I. N. Kapustin (1988), Horizontal movements and dynamics of a sedimentary cover formation in Phanerozoic, in Intraplate Phenomena in the Earth's Crust, edited by V. E. Khain, p. 38, Nauka, Moscow.

Bronguleev, V. V., (Ed.) (1978), Maps of Thickness of Paleozoic Sediments on the East European Platform, Scale 1:5,000,000, 30 pp., Centergeologia, Moscow.

Dedeev, V. A., (Ed.) (1982), Structure of a Platform Cover of the Northern European Part of the USSR, 200 pp., Nauka, Leningrad.

Dedeev, V. A., L. Z. Aminov, and V. G. Getsen (1986), Tectonic Criteria of the Oil and Gas Forecast of the Pechora Plate, 217 pp., Nauka, Leningrad.

Garetsky, R. G. (1991), Basic problems of platform tectonics study, Geotectonics, 25(5), 3.

Garetsky, R. G., L. G. Kirjuhin, and I. N. Kapustin (1990), Non-Compensated Basins of East-European Platform, 102 pp., Nauka and Technics, Minsk.

Getsen, V. G. (1991), Geodynamic reconstruction of the Late Proterozoic history of the North-East part of the European part of the USSR, Geotectonics, 25(5), 26.

Grachev, A. F. (1987), Rift Zones of the Earth, 2nd ed., 287 pp., Nedra, Moscow.

Grachev, A. F., and V. S. Fedorovsky (1970), On the unified nature rifts, aulacogens and geosyncline troughs, Soviet Geology, 12(12), 121.

Grachev, A. F., V. G. Nikolaev, and K. B. Seslavinsky (1994), Evolution of structure, sedimentation and magmatism of the East European platform in the Late Precambrian and Paleozoic, in Tectonics and Magmatism of East-European Platform, edited by Yu. G. Leonov, p. 5, Geo-Inveks, Moscow.

Khain, V. E. (1984), Regional Tectonics, 344 pp., Nedra, Moscow.
Lukin, A. E., A. S. Vladimirov, and I. M. Ermakov (1992), Problems of predevonian rifting in Dniepr-Donetsk aulacogene, Geotectonics, 26(2), 30.

Malushin, I. I. (1987), Caspian megadome and connected with it southern continental rift system, Geotectonics, 21(2), 61.

Proskuryakov, V. V., L. I. Uvadev, and V. A. Zhuravlev (1989), Alkaline potassium rocks of Kostomiksha ore region (Western Karelia), Reports of the USSR Acad. Sci., 307, 1457.

Seslavinsky, K. B. (1987), Caledonian Sedimentation and Volcanism in the Earth's History, 192 pp., Nedra, Moscow.

Shakhnovsky, I. M. (1988), Geological Structure and Oil and Gas of Aulacogens of East-European Platform, 120 pp., Nauka, Moscow.

Sharipov, E. E. (1975), Early platform structures of the eastern part of the Russian platform, Bull. Moscow Society of Nat. Sci. Geol. Sect., L, 32.

Shatsky, N. S. (1964), The Selected Works, vol. II, 720 pp., Nauka, Moscow.

Volozh, J. A. (1990), Seismostratigraphic model of PaleozoicMesozoic basins of Western Kazakhstan, in Seismostratigraphic Investigations of Oil Fields and Gas, vol. 1, p. 139, Nedra, Moscow.

Yanshin, A. L., E. V. Artyushkov, and R. G. Garetsky (1979), Comparative characteristic of deep structure and history of development of the Turanian plate and PriCaspian basin, in Tectonics of the USSR, p. 59, Nauka, Moscow.

Zhuravlev, V. S. (1972), Comparative tectonics of Pechora, PriCaspian and North Sea basins of East European platform, Geol. Institute Proceedings, Issue 232, p. 339, Nauka, Moscow.

A. F. Grachev, V. A. Nikolaev, Institute of Physics of the Earth, Russian Academy of Sciences, 10 Bol'shaya Gruzinskaya ul., Moscow, 123995 Russia (e-mail: grachev@ifz.ru)

V. G. Nikolaev, Geological Institute, Russian Academy of Sciences, 7 Pyzhevskiy Lane, Moscow, 119017 Russia 